\title{
The assemblages of transparent heavy minerals in Quaternary sediments of the Kielce-Łagów Valley (Holy Cross Mountains, Poland)
}

\author{
Małgorzata Ludwikowska-Kędzia \\ Department of Palaeogeography, Geoecology and Nature Protection, Institute of Geography, \\ Jan Kochanowski University, Kielce, Poland; e-mail: mlud@ujk.kielce.pl
}

\begin{abstract}
The composition of the transparent heavy-mineral assemblages $(0.25-0.1 \mathrm{~mm})$ in Quaternary slope, karst, glacial, fluvioglacial and fluvial deposits with different parent material was investigated in the Kielce-Łagów Valley (the central part of the Palaeozoic core of the Holy Cross Mountains). For the purpose, 93 samples of mostly sandy sediments were examined. Some marker and some supporting minerals can be distinguished. Slope and karst deposits are dominated by the abrasion-resistant minerals zircon, tourmaline, staurolite and rutile. This assemblage points at a source consisting of strongly weathered pre-Quaternary bedrock. Glacial and fluvioglacial deposits are dominated by medium-resistant and non-resistant minerals (garnet, amphibole, pyroxene and biotite). The two types of parent material of the heavy minerals are typical of the Quaternary deposits in the Polish uplands. The two sources are most clear in the younger (Vistulian and Holocene), mostly fluvial sediments. The results of the analysis imply that the impact of Pleistocene glaciers on the central part of the Holy Cross Mountains was neither large enough to hide the local mineralogical background, nor sufficient to dominate over the main processes transforming the mineral composition under the variable climatic conditions of the Quaternary, including aeolian processes and chemical weathering.
\end{abstract}

Key words: heavy-mineral analysis, Quaternary deposits, Holy Cross Mountains

\section{Introduction}

The Holy Cross (Świętokrzyskie) Mountains are located in the morphogenetic zone of Polish uplands and old mountains (Gilewska, 1991; Starkel, 2008), where Palaeozoic outcrops are locally covered by unconsolidated sediments. This cover comprises deposits that accumulated under various climatic conditions during the Palaeogene-Neogene, the Pleistocene glacials and periglacial phases, and the Holocene (Łyczewska, 1971; Linder, 1984; Mojski, 2005). Thus, the Quaternary of the Holy Cross Mountains contains material from reworked, weath- ered bedrock, as well as from older glacial and fluvioglacial deposits, as a consequence of the cover by Pleistocene ice sheets (Lindner, 2004; Marks, 2011).

Under periglacial conditions, the relief of the Holy Cross Mountains affected the sediments, which underwent modifications, mostly due to denudation, fluvial activity, weathering and aeolian processes. Deposits accumulated in several sedimentary environments can consequently be found side by side, also at similar elevations. This complex character was thus far insufficiently discussed in the literature dealing with the region. 


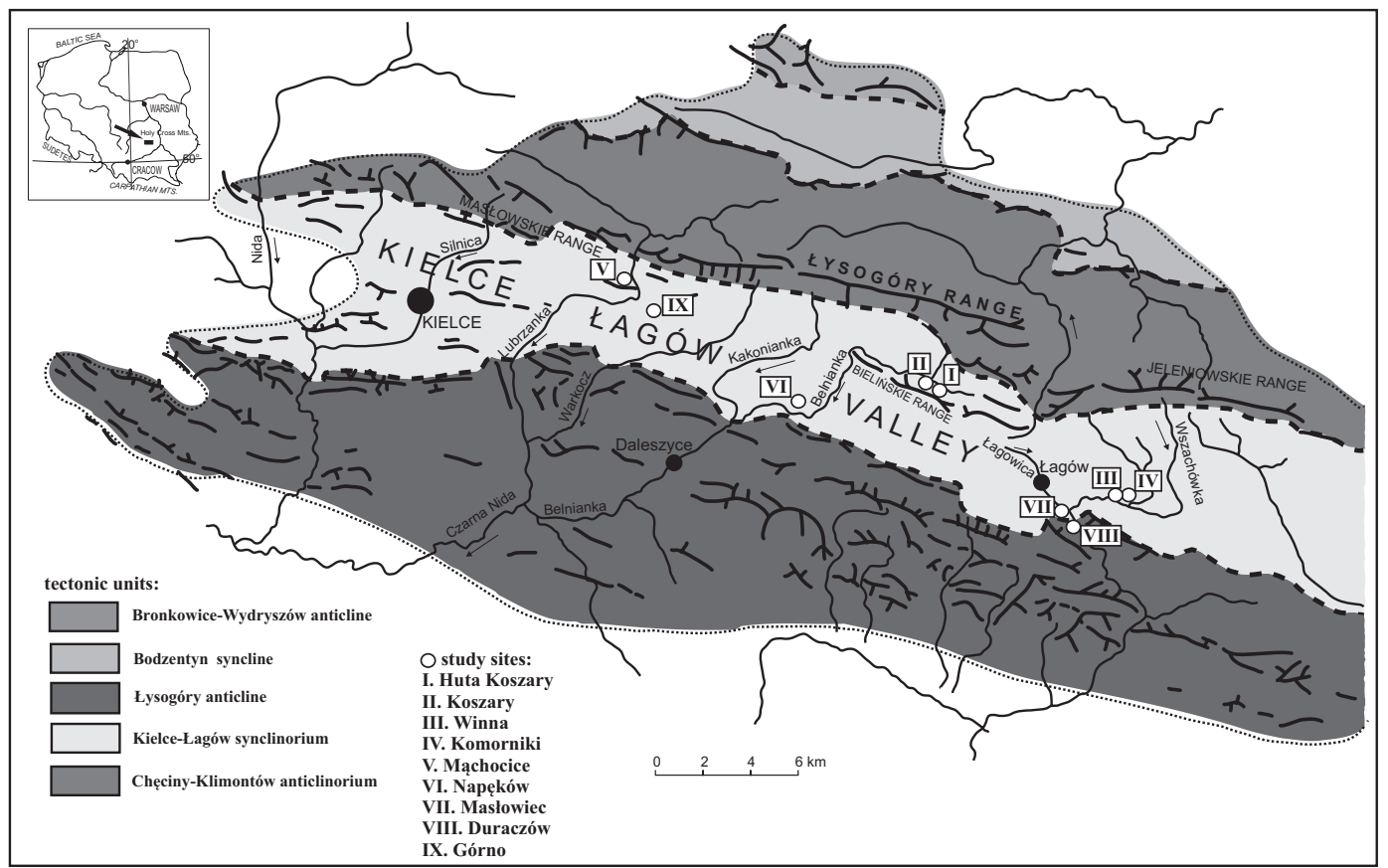

Fig. 1. Location of the study area and of sites I-IX in the Kielce-Łagów Valley, also showing the tectonic units of the Holy Cross Mountains (from Wróblewski, 1977, and Czarnocki, 1957).

It was therefore decided to investigate the Quaternary deposits of a specific stratigraphic position in the central part of the mountain range; the deposits represent various sedimentary environments, viz. slope, glacial, fluvioglacial and fluvial sediments, in combination with older deposits that are considered as parent material for the Quaternary cover, i.e. Miocene deposits filling karst pits, and weathered material of the Palaeozoic rocks. The latter aspect has so far hardly been dealt with in the literature (Radłowska \& Mycielska-Dowgiałło, 1972; Kowalski et al., 1979; Ludwikowska-Kędzia, 2000, 2007; Ludwikowska-Kędzia et al., 2006).

The objective of the study was to identify the characteristic qualitative and quantitative features of the heavy-mineral composition of these Quaternary deposits, taking the mineralogical features of the possible or probable parent material into consideration. The study should thus lead to identification of the local and regional parent material of the Quaternary deposits in the central part of the Holy Cross Mountains. This, in turn, should result in data that are useful for establishing a better lithostratigraphy of the Holy Cross Mountains. The Kielce-Łagów Valley was chosen for the study because it forms a vast, structural depression in the central part of the Holy Cross Mountains (Fig. 1).

\section{Study area and locations of the study sites}

The depression of the Kielce-Łagów Valley (300 m above sea level - a.s.1.) coincides with the structural boundaries of the KielceŁagów synclinorium in the Palaeozoic core of the mountain range (Fig. 1). In the North and the South, the valley is bordered by mountain ranges with a maximum elevation of 612 $\mathrm{m}$ a.s.l., built by Cambrian quartz sandstones, shales and greywackes.

The bottom of the valley consists of Silurian, Devonian (mainly limestones, dolomites, sandstones and greywackes), and locally of Carboniferous shales. In the area with carbonate rocks, the bedrock shows a fossil karst relief (Urban, 2001; Rzonca \& Urban, 2009), buried under a cover of Quaternary deposits of various types and ages. Due to the karst relief, the thickness of the Quaternary in the valley bottom varies from 30 to $40 \mathrm{~m}$; it decreases from NW to SE. The selection of the various sites was based on the relationship between the Quaternary and 
the area's relief. The study concerned deposits representing different forms of relief (fossil or contemporary) and different environments: slope, glacial and fluvial.

Samples from nine study sites of different ages were collected for the heavy-mineral analysis. Two are located on the north-eastern slope of the Bieliny range, near Huta Stara Koszary (site I) and near Koszary (site II) (Fig. 1). At both sites the analysis concerned debris of the Devonian sandstone building the Bieliny range. The heavy-mineral composition of the deposits filling the karst pits was studied in the Winna quarry (site III) and in the Komorniki quarry (site IV). Glacigenic deposits were analysed at the sites Mąchocice (site V) and Napęków (site VI). Periglacial fluvial-slope deposits were examined at Masłowiec (site VII) and fluvial deposits were sampled at Duraczów (site VIII) and Górno (site IX).

\section{Methods}

The textural and structural features are described through the lithofacies codes proposed by Miall $(1978,1985)$, as modified by Zieliński \& Pisarska-Jamroży (2012). The stratigraphic position of the deposits was established by TL and OSL datings, and named in accordance with the general stratigraphical subdivision of the Quaternary of Poland; correlation with the Western European stratigraphy follows Marks (2011) and Lindner \& Marks (2012) (Fig. 2).

The various units are indicated with a code that is based on the type of deposit, its lithology, its age and the number of the study site. As an example, unit $\mathrm{Ss}-\mathrm{O}_{\mathrm{I}}$ refers to a slope deposit $(\mathrm{S})$, which is sandy (s) and of Odranian age (O) at study site I. Regarding the type of deposit, 6 types are distinguished: slope (S), weathered bedrock $(W)$, karst infilling $(K)$, glacial $(G)$, glaciofluvial (FG) and fluvial (F). Three types of lithology are distinguished: sand (s), till (t), and debris or scree (d). Sediments of the following ages are studied: Devonian (D), Miocene (M), Odranian (O), Krznanian (K), Lublinian (L), early Vistulian (EV) and Pleniglacial (P). The various sites are coded according to their number (I-IX).

The heavy minerals from 93 samples of sand, sandy gravel, till and weathered debris of Devonian sandstones were analysed for the $0.10-0.25 \mathrm{~mm}$ size fraction. The results of the various deposits are presented in Tables 1-6, also classified according to their resistance to chemical weathering and mechanical abrasion following Racinowski (1995). The group of resistant minerals consists of tourmaline (tou, T), zircon (zir, Z), rutile (rut, R), titanite
Fig. 2. General stratigraphical subdivision of the Quaternary of Poland and its correlation with Western Europe (after Marks, 2011). The glacial episodes in Poland are indicated in bold.

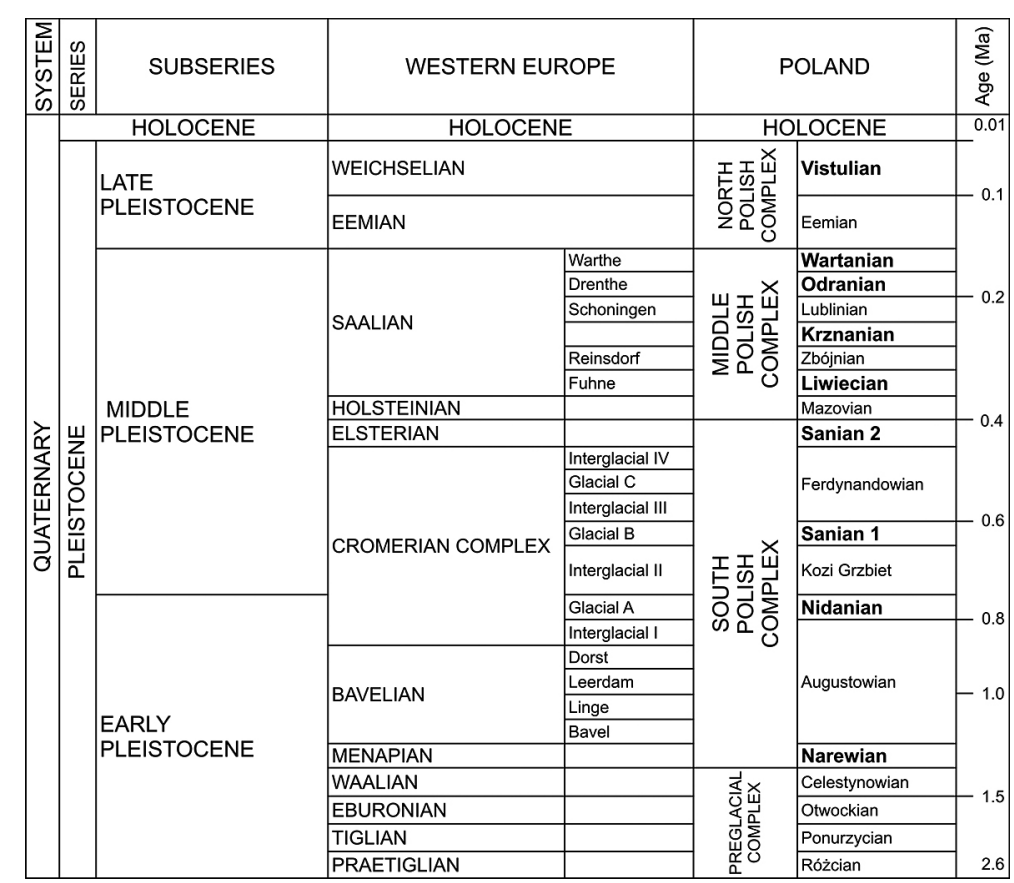


(tit, TI), kyanite (kya, K), staurolite (stau, ST), andalusite (and, AN) and topaz (top, TO). The semi-resistant minerals are epidote (epi, E), garnet (gar, G), sillimanite (sil, S) and apatite (apa, AP). The non-resistant minerals are amphibole (amp, AM), pyroxene (pyr, P), glauconite (gla, GL), biotite (bio, B), muscovite (mus, $\mathrm{M})$, and chlorite (ch, $\mathrm{CH}$ ).

The weathering index (W) was calculated for the analysed sediments after Racinowski \& Rzechowski (1969), as defined by the formula $\mathrm{W}=(\mathrm{SR} / \mathrm{R}) \mathrm{NR}$ (percentage of semi-resistant minerals (SR) divided by the percentage of resistant minerals (R), multiplied by the percentage of non-resistant minerals (NR). The calculation is based on the proportion of transparent minerals of different resistance in the deposit. The group of transparent minerals $(\mathrm{T})$ is taken as $100 \%(\mathrm{~T}=100 \%)$ and acts as the basis for the calculations.

The analog weathering index $(\mathrm{aW})$ proposed by the present author, is based on the same formula, but the difference is that the total sum of transparent $(\mathrm{T})$ and opaque $(\mathrm{O}) \mathrm{min}$ erals, i.e. the whole group of heavy minerals from the sample $(\mathrm{T}+\mathrm{O}=100 \%)$ is taken as the starting point for the calculations. The methodology using aW calculations results from adopting the following assumptions:

1) the assemblage of transparent heavy minerals (T) is an integral part of the total heavy-mineral assemblage, and should not be analysed without also analysing the opaque mineral group $(\mathrm{O})$;

2) the relationship between the proportion of the transparent mineral $(\mathrm{T})$ and the opaque minerals $(\mathrm{O})$, i.e. the proportionality index $(\mathrm{P}=\mathrm{T} / \mathrm{O})$, defines specific conditions of the sedimentary environment (Marcinkowski, 2007); the lower the proportionality index, the higher the proportion of opaque minerals in a sediment; in the mineral analysis of a sediment, the characteristics of the opaque heavy minerals are then consequently more important for interpretations (the characteristics being increasingly better recognisable with a decreasing proportionality index; see, e.g., Barczuk \& Nejbert, 2008);

3) In both $W$ and aW, the ratio SR/R (semi-resistant to resistant) is the same. The ultimate val- ue of these indexes is affected by the proportion of non-resistant transparent minerals.

The heavy-mineral composition of the transparent minerals can, as suggested by Racinowski (2008), be subdivided into dominant and supporting minerals. The dominant minerals are the most frequent species that jointly make up more than $50 \%$; they are indicated with capital letters. Supporting minerals are the species that are quantitatively similar to the least frequent dominant mineral; they are indicated with lower-case letters between brackets.

\section{Geomorphology, lithology and age of the deposits}

\subsection{The Huta Stara Koszary site (I)}

The slope deposits at the Huta Stara Koszary site constitute the higher part of the less inclined slope under the steeper north-eastern rocky slope of the Bieliny range; the steep rocky slopes are built of Devonian quartz sandstones (Fig. 3A). The less inclined slopes, consisting of slope material are located between 350 and $355 \mathrm{~m}$ a.s.l. Two successions of different lithology and age are distinguished (Fig. 3B) (Ludwikowska-Kędzia, 2007, Ludwikowska-Kędzia \& Olszak 2009): (1) a sandy, gravelly/sandy and gravelly unit $\left(\mathrm{Ss}_{\mathrm{S}} \mathrm{O}_{\mathrm{I}}\right)$, dating from the Odranian glaciation (MIS 6, Drenthian glaciation of the Saalian, Fig. 2), accumulated due to the denudation of sandy and gravelly sandy covers of local weathered material from the Devonian bedrock $\left(\mathrm{Wd}-\mathrm{D}_{\mathrm{I}}\right)$, and of fluvioglacial deposits; and (2) a periglacial till unit (St- $\mathrm{P}_{\mathrm{r}}$ ) and a sandy unit (Ss- $\mathrm{P}_{\mathrm{I}}$ ) dating from the early and middle Pleniglacial (= Weichselian, MIS 3, MIS 2; Fig. $2)$. In the lower part of the till unit, the tills are massive, whereas they become layered higher op. These deposits originated by denudation of the coarse-grained weathering covers of the Palaeozoic bedrock, of Odranian deposits and loess, but mostly as a result of solifluction of unsorted material with different densities, which started moving due to ablation.

The heavy minerals of 24 samples (numbers 1-24) from deposits at the Huta Stara Koszary site have been analysed (Table 1). 


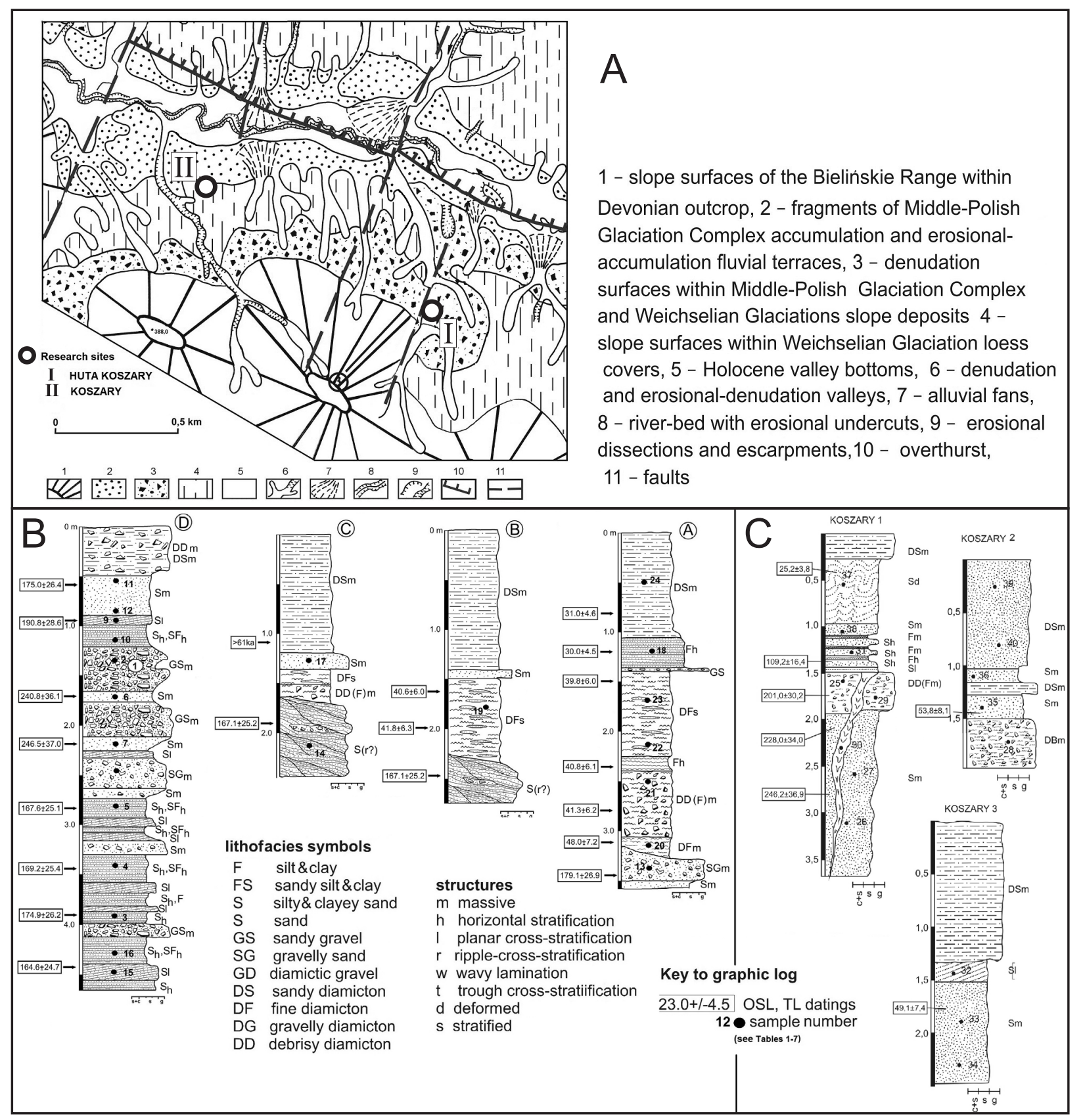

Fig. 3. Study sites Huta Koszary (site I) and Koszary (site II).

A: The sites in their (schematic) geomorphological context of the northern slopes of the Bielińskie Range.

B: Sedimentological logs of the slope deposits at site Huta Koszary (modified after Ludwikowska-Kędzia, 2007; Ludwikowska-Kędzia \& Olszak, 2009).

C: Sedimentological logs of the slope deposits at site Koszary (modified after Ludwikowska-Kędzia, 2007; Ludwikowska-Kędzia \& Olszak, 2009).

\subsection{The Koszary site (II)}

The Koszary site is located where the erosion and denudation processes gradually pass into the lower level of the less inclined slope under the steeper slope with Devoni- an rocks in the Bieliny range, ending at the bottom of the Belnianka river (Fig. 3A). Just like at site I, two units of slope deposits with different age and lithology are distinguished: (1) a complex dating from the Middle Polish complex (= Saalian), and (2) a complex dating 


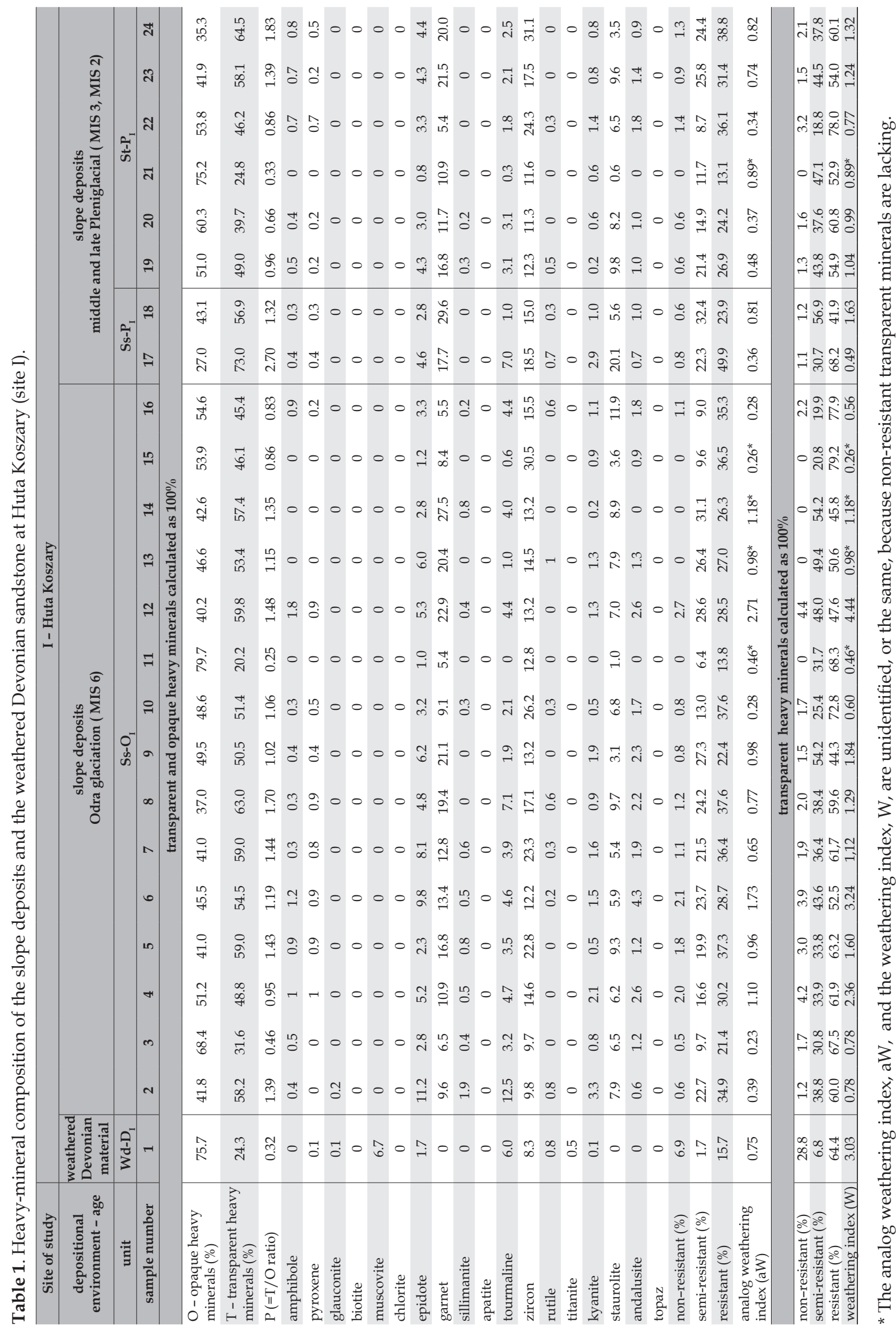




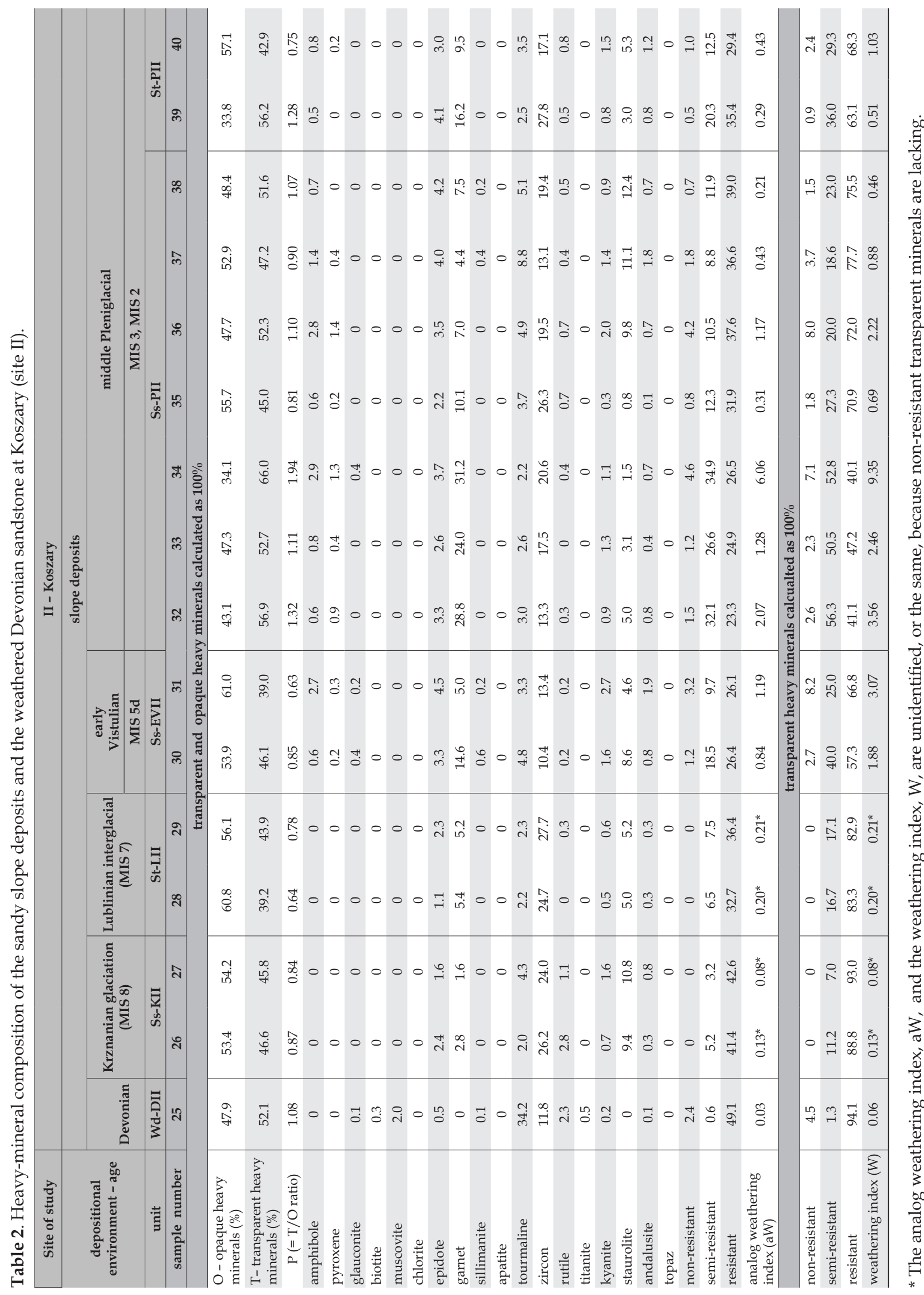



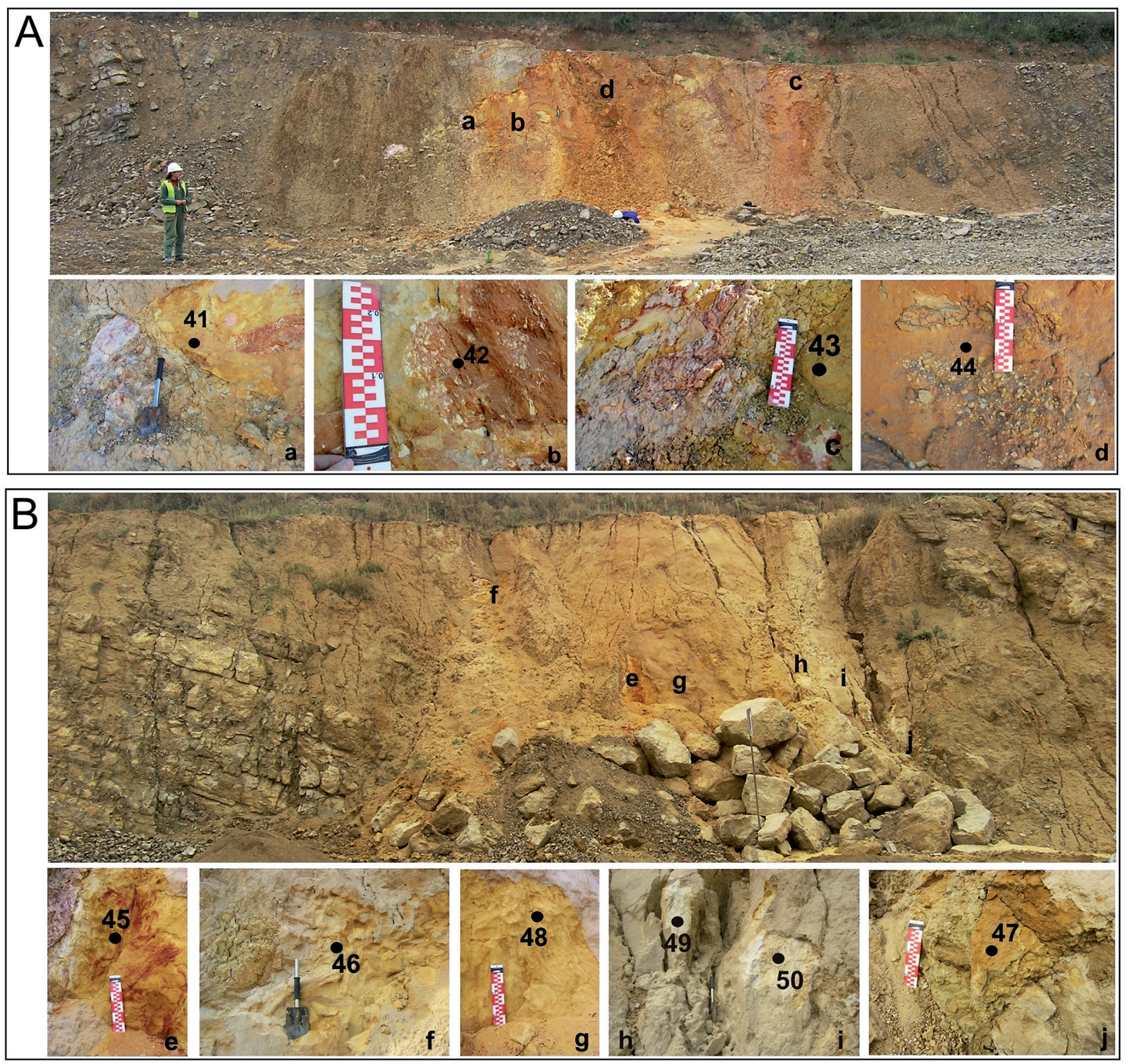

Fig. 4. Karst pits and their infillings, with sampling sites. Numbers of samples are indicated (see Table 3).

A: The dolomite quarry at Winna (site III).

B: The dolomite quarry at Komorniki (site IV).

from the North-Polish complex $(=$ Vistulian $=$ Weichselian) (Fig. 3C).

The periglacial, Middle-Polish complex of slope deposits is represented by (a) a unit (Ss$\left.\mathrm{K}_{\mathrm{II}}\right)$ that is sandy/silty in its lower part and sandy in its upper part, dating from the Krznanian glaciation of the Saalian (MIS 8, a glacial episode in Poland; Fig. 2), with locally lenses of debris from heavily weathered local Devonian quartz sandstones $\left(\mathrm{Wd}-\mathrm{D}_{\mathrm{II}}\right)$; and (b) a till unit $\left(\mathrm{St}-\mathrm{L}_{\mathrm{II}}\right)$, consisting of clast-rich diamictons and sandy diamictons dating from the Lublinian interstadial (Saalian, Schoningen, MIS 7) (Fig. 2) formed by solifluction.

The Vistulian periglacial complex is represented by (c) a sandy unit (Ss-EV $\mathrm{II}_{\mathrm{II}}$ ) dating from the early Vistulian (= Weichselian, MIS 5d), with ice-wedge casts that were transformed by slope processes, (d) a sandy unit (Ss- $\mathrm{P}_{\mathrm{II}}$ ) dating from the middle Pleniglacial (MIS 3) with, in the upper part of the exposures, deformed sands with clearly visible ferruginous streaks, and (e) a till unit $\left(\mathrm{St}-\mathrm{P}_{\mathrm{II}}\right)$ consisting of a silty/clayey, locally 
Table 3. Heavy-mineral composition of the sandy infillings in karst pits at Winna (site III) and Komorniki (site IV).

\begin{tabular}{|c|c|c|c|c|c|c|c|c|c|c|}
\hline Site of study & \multicolumn{4}{|c|}{ III - Winna } & \multicolumn{6}{|c|}{ IV - Komorniki } \\
\hline $\begin{array}{l}\text { depositional } \\
\text { environment - age }\end{array}$ & \multicolumn{10}{|c|}{$\begin{array}{l}\text { infillings of karst pits } \\
\text { Neogene-Palaeogene - Miocene? }\end{array}$} \\
\hline unit & \multicolumn{5}{|c|}{ Ks-M } & \multicolumn{5}{|c|}{ Ks-M $\mathbf{M}_{\mathrm{IV}}$} \\
\hline sample number & 41 & 42 & 43 & 44 & 45 & 46 & 47 & 48 & 49 & 50 \\
\hline \multicolumn{11}{|c|}{ transparent and opaque heavy minerals calculated as $100 \%$} \\
\hline $\begin{array}{l}\text { O - opaque } \\
\text { heavy minerals }(\%)\end{array}$ & 46.7 & 34.7 & 37.6 & 60.5 & 87.7 & 44.9 & 70.1 & 40.9 & 39.3 & 42.4 \\
\hline $\begin{array}{l}\mathrm{T} \text { - transparent } \\
\text { heavy minerals }(\%)\end{array}$ & 53.3 & 65.3 & 62.4 & 39.5 & 15.3 & 55.1 & 29.9 & 59.1 & 60.7 & 57.8 \\
\hline $\mathrm{P}(=\mathrm{T} / \mathrm{O}$ ratio $)$ & 1.14 & 1.88 & 1.65 & 0.65 & 0.18 & 1.23 & 0.43 & 1.44 & 1.54 & 1.36 \\
\hline amphibole & 6.7 & 10.5 & 3.6 & 3.6 & 4.0 & 5.5 & 1.6 & 12.8 & 12.6 & 6.9 \\
\hline pyroxene & 0.8 & 0.8 & 0.5 & 0.6 & 0.3 & 0.7 & 0.2 & 1.2 & 0.7 & 0.8 \\
\hline glauconite & 0.3 & 0 & 0.2 & 0 & 0 & 0 & 0 & 0 & 0 & 0.4 \\
\hline biotite & 0 & 0 & 0 & 0 & 0 & 0 & 0 & 0 & 0 & 0 \\
\hline muscovite & 0 & 0 & 0.1 & 0 & 0 & 0 & 0 & 0 & 0 & 0 \\
\hline chlorite & 0 & 0 & 0.1 & 0 & 0 & 0 & 0 & 0.3 & 0 & 0 \\
\hline epidote & 0 & 0 & 0 & 0.3 & 0 & 0 & 0 & 0 & 0.1 & 0.8 \\
\hline garnet & 0.1 & 0 & 0 & 0.3 & 0.1 & 0 & 0 & 0.3 & 0 & 0.2 \\
\hline sillimanite & 0 & 0.1 & 0.3 & 0 & 0 & 0.1 & 0.3 & 0 & 0.3 & 0 \\
\hline apatite & 0 & 0.4 & 1.3 & 0.3 & 0 & 0.1 & 0 & 0.6 & 0.3 & 0.4 \\
\hline tourmaline & 8.3 & 4.4 & 3.4 & 1.1 & 0.4 & 4.4 & 1.9 & 7.6 & 4.7 & 3.8 \\
\hline zircon & 5.3 & 5.9 & 15.0 & 6.0 & 2.5 & 11.5 & 6.9 & 4.4 & 11.5 & 10.7 \\
\hline rutile & 5.6 & 8.9 & 8.6 & 5.9 & 2.1 & 3.1 & 2.4 & 4.9 & 7.0 & 5.5 \\
\hline titanite & 0 & 0.9 & 0.9 & 1.1 & 0 & 0.2 & 0.4 & 0.9 & 1.0 & 1.3 \\
\hline kyanite & 10.2 & 20.7 & 18.0 & 11.6 & 0.3 & 14.4 & 6.1 & 6.4 & 6.7 & 4.2 \\
\hline staurolite & 14.1 & 11.2 & 9.6 & 7.4 & 5.4 & 11.2 & 7.8 & 17.7 & 14.5 & 20.8 \\
\hline andalusite & 1.4 & 1.3 & 0.6 & 1.3 & 0.1 & 2.5 & 1.4 & 2.0 & 0.7 & 1.0 \\
\hline topaz & 0.5 & 0.2 & 0.2 & 0 & 0.1 & 1.4 & 0.9 & 0 & 0.6 & 1.0 \\
\hline non-resistant & 7.8 & 11.3 & 4.4 & 4.2 & 4.3 & 6.2 & 1.8 & 14.3 & 13.4 & 8.1 \\
\hline semi-resistant & 0.1 & 0.5 & 1.6 & 0.9 & 0.1 & 0.2 & 0.3 & 0.9 & 0.6 & 1.4 \\
\hline resistant & 45.4 & 53.5 & 56.3 & 34.4 & 10.9 & 48.7 & 27.8 & 43.9 & 46.7 & 48.3 \\
\hline analog weathering index (aW) & 0.02 & 0.11 & 0.13 & 0.11 & 0.04 & 0.03 & 0.02 & 0.29 & 0.17 & 0.23 \\
\hline \multicolumn{11}{|c|}{ transparent heavy minerals calculated as $100 \%$} \\
\hline non-resistant & 14.7 & 17.3 & 7.2 & 11.8 & 27.9 & 11.2 & 5.9 & 24.1 & 22.2 & 14.1 \\
\hline semi-resistant & 0.3 & 0.7 & 2.5 & 2.2 & 0.9 & 0.4 & 1.1 & 1.5 & 0.9 & 25.0 \\
\hline resistant & 85.0 & 82.0 & 90.3 & 87.0 & 71.1 & 88.4 & 93.0 & 74.4 & 76.9 & 83.4 \\
\hline weathering index (W) & 0.05 & 0.15 & 0.20 & 0.30 & 0.35 & 0.05 & 0.07 & 0.49 & 0.26 & 0.42 \\
\hline
\end{tabular}

sandy, diamicton with clasts of local rocks, dating from the late Pleniglacial (MIS 2).

Heavy minerals of 16 samples (numbers 2540) from deposits at the Koszary site have been analysed (Table 2).

\subsection{The Winna (III) and Komorniki (IV) sites}

Sandy Miocene sediments at both the Winna site (with unit Ks-M $\mathrm{M}_{\text {III }}$ ) (Fig. 4A) and the Komorniki site (with unit Ks-M ${ }_{\text {IV }}$ ) (Fig. 4B) belong to the so-called 'Tertiary land complex' (an informal unit) (Fijałkowska \& Fijałkowski,
1971); they form infillings of karst pits in the Devonian dolomites near Łagów (Fig. 1). The sediments comprise sandy and gravelly sediments, but primarily clayey/silty sediments, so-called 'potter's clays'. The sandy, massive, locally glacitectonically deformed sediments are regarded as the weathering products of various types of sandstone from the Holy Cross region (Fijałkowska \& Fijałkowski, 1971).

The heavy minerals of 4 samples (numbers 41-44) from deposits at the Winna site and of 6 samples (numbers 45-50) from deposits at the Komorniki site have been investigated (Table $3)$. 

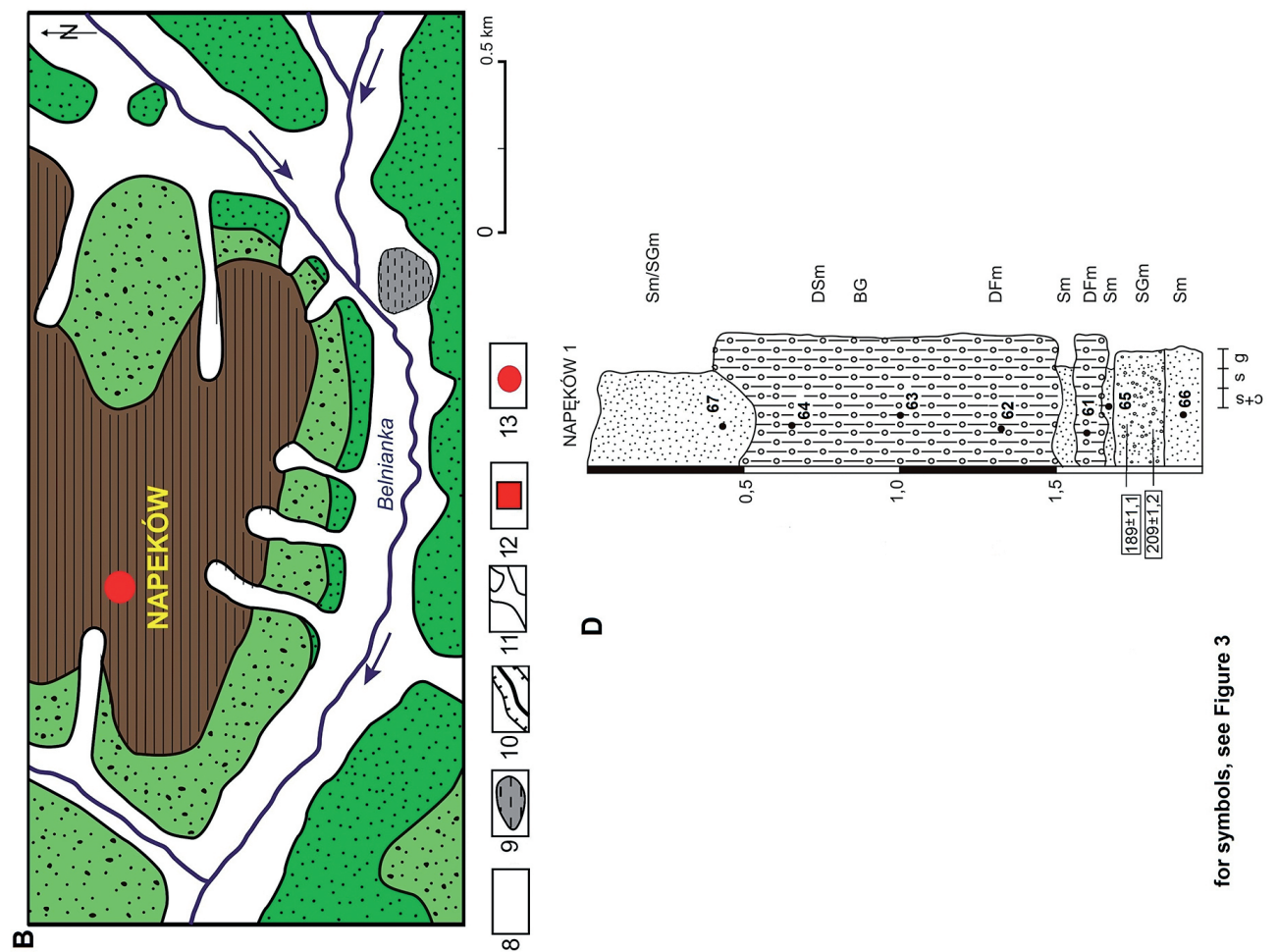

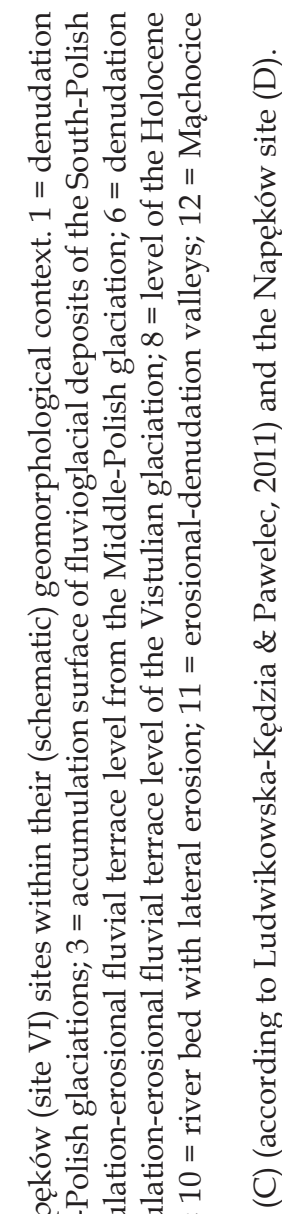
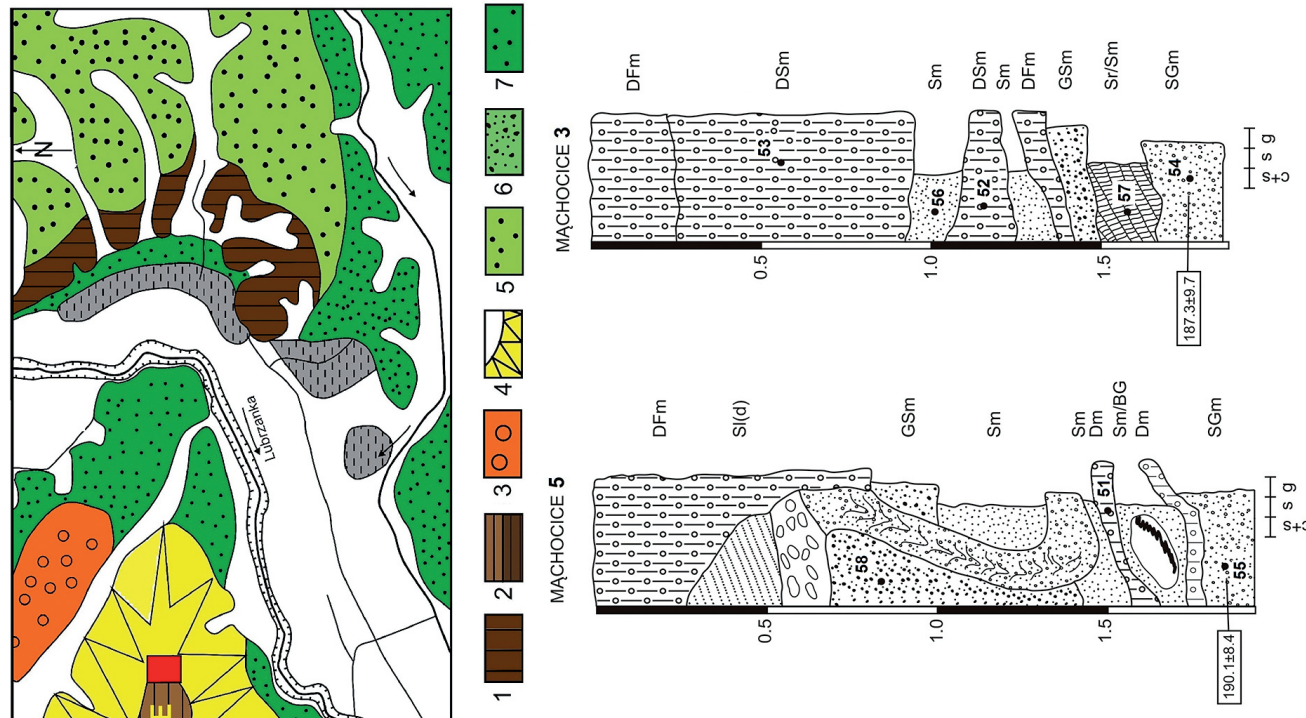

○
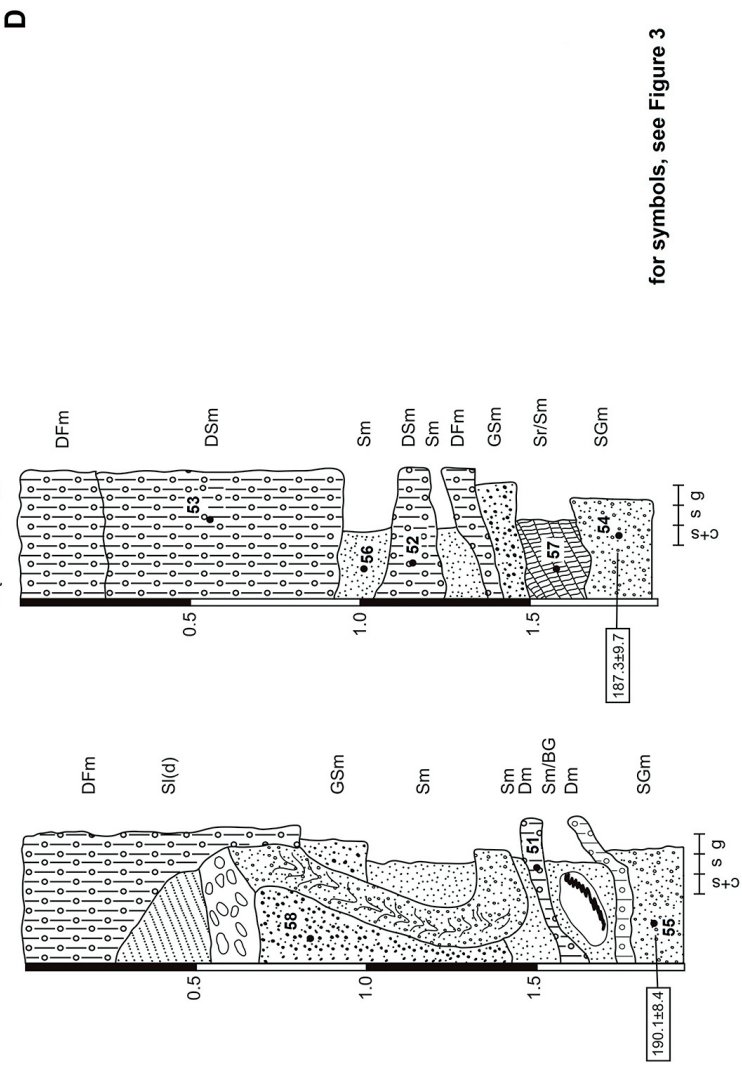

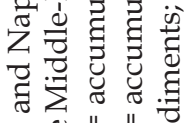

ऽ

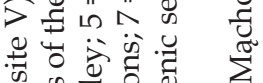

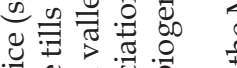

记

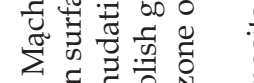

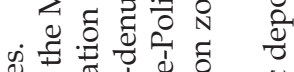

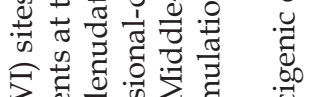

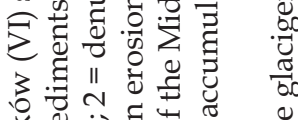

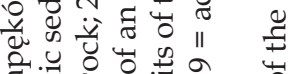

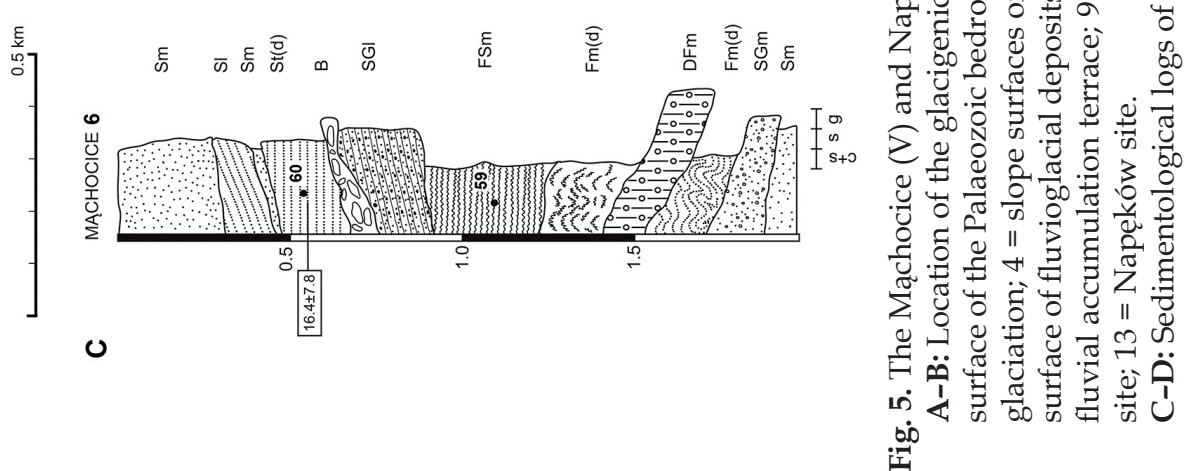




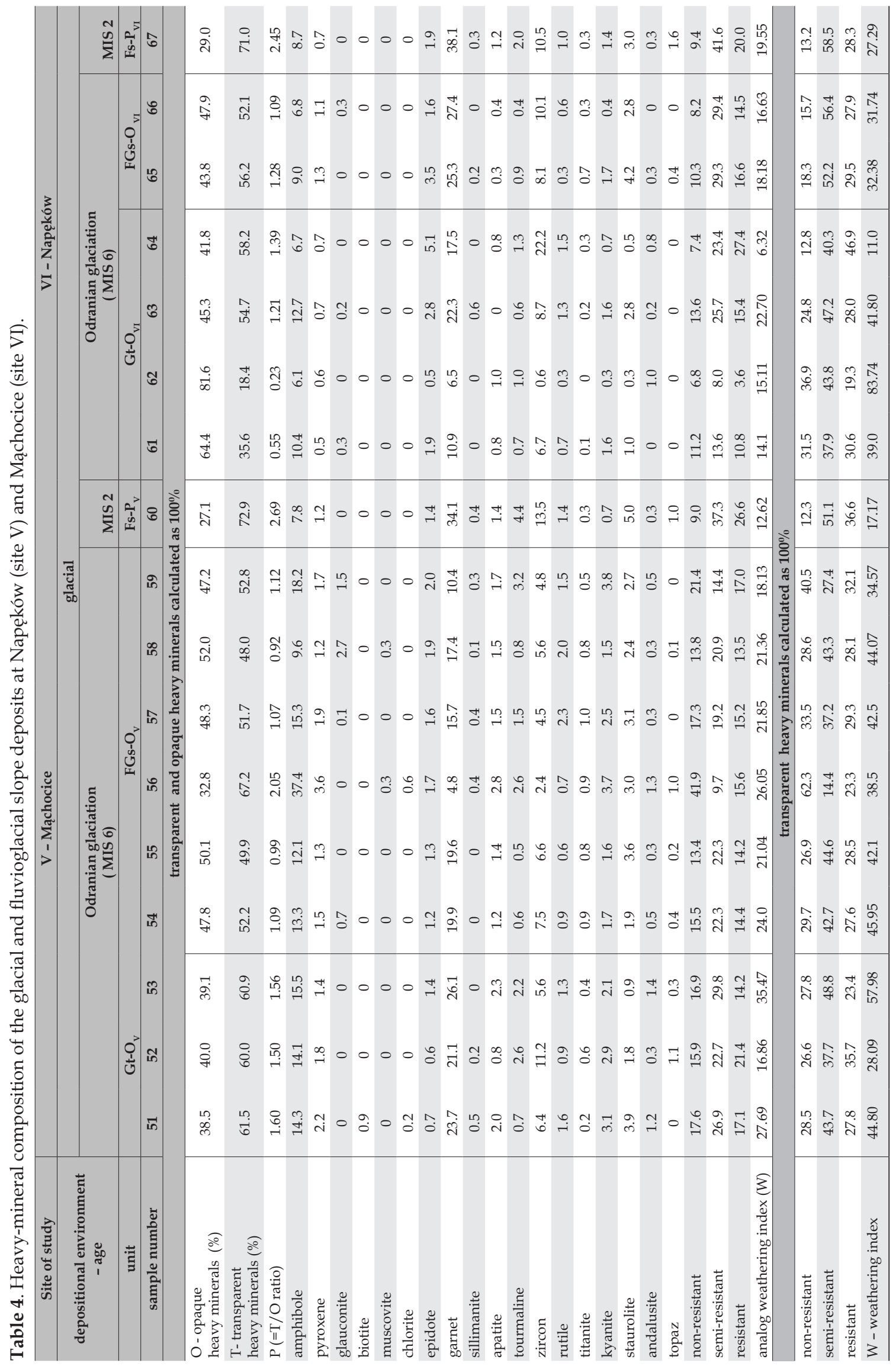




\subsection{The Mąchocie (V) and Napęków (VI) sites}

Both the Mąchocice and Napęków sites are located within a denudation area of glacigenic sediments (Fig. 5A-B), at an elevation of 280-290 m a.s.l. The sediments were deposited during the Odranian glaciation (MIS 6, Drenthe glaciation of the Saalian) (Fig. 2). On the basis of preliminary facies, microfacies and petrographical analyses of the sediments (Ludwikowska-Kędzia \& Pawelec, 2011; Kubala- Kukuś et al., in press), two units are distinguished: (Fig. 5C-D): (1) a sandy, sandy/gravelly unit $\left(\mathrm{Ss}_{-}-\mathrm{O}_{\mathrm{V}} \mathrm{Ss}-\mathrm{O}_{\mathrm{VI}}\right)$ underlying tills, and (2) a flow-till unit $\left(\mathrm{St}-\mathrm{O}_{\mathrm{v}}, \mathrm{St}_{-} \mathrm{O}_{\mathrm{VI}}\right)$.

The sediments were deposited in a glaciomarginal environment, in the direct neighbourhood of a stagnant or retreating head of the glacier lob, presumably within an area of glaciomarginal fans. During the Vistulian they were modified by periglacial processes.

The heavy minerals of 10 samples (numbers: 51-60) from deposits at the Mąchocice site and of 7 samples (numbers 61-67) from deposits at the Napęków site have been investigated (Table 4).

\subsection{The Masłowiec (VII) and Duraczów (VIII) sites}

The deposits at Masłowiec, accumulated by a stream with admixtures of slope material from the valley walls and the fluvial deposits at Duraczów are situated in the upper Łagowica valley (Fig. 6A). From Łagów to Nowy Staw, the valley has the character of a karst gorge, incised into limestones and dolomites of the Middle Devonian (Walczowski, 1962, 1964, 1968; Łyczewska, 1971). Downstream of Nowy Staw and the Wszachówka river estuary, the valley bottom widens, and shows a flat bottom (Fig. $6 \mathrm{~A})$. Both study sites contain sediments typical of the Pleniglacial terrace level (Weichselian, MIS 3, MIS 2), which is situated at an elevation of 275-285 $\mathrm{m}$ a.s.l. (i.e. 8-10 $\mathrm{m}$ above the present-day floodplain). The Masłowiec site is situated in the deeply incised segment of the valley, whereas the Duraczów site is located on the flat valley bottom.

On the basis of textual and structural features, the Masłowiec deposits can be subdivided into four genetic units: A, B, C (with sub-units $\mathrm{C} 1$ and $\mathrm{C} 2$ ) and D (Fig. 6B) (Ludwikowska-Kędzia et al., 2006) Unit A (Fs- $\mathrm{P}_{\text {VII }}$ ) includes sandy, fluvial sediments, with sporadical gravelly/clayey packets of weathered Devonian sandstones. Large pieces of the Lower Devonian sandstone bedrock are present at the base of this unit. Unit B (Ss-P $\left.\mathrm{VII}_{\mathrm{VI}}\right)$, consisting of slope deposits, is built by sandy silts with a rhythmic character, with intercalated layers of massive sands. Unit $C$ is built of sandy fluvial sediments with admixtures of slope material. The lower part of the unit, sub-unit $\mathrm{C} 1$ (Fs- $\left.\mathrm{P}_{\mathrm{VII}}\right)$, represents a fluvial environment, whereas the upper part, sub-unit C2 (Ss- $\left.\mathrm{P}_{\mathrm{VII}}\right)$, represents a slope environment. The unit contains post-depositional deformation structures, interpreted as a result of unstable density gradients (cf. Anketell et al., 1979), thus forming graviturbations sensu Van Loon (2009). Unit $\mathrm{D}\left(\mathrm{Ss}-\mathrm{P}_{\mathrm{VII}}\right)$ has a slope origin and represents a solifluction process. The basal part of the unit contains silty clay with numerous masses of strongly weathered sandstone, underlain by irregular very fine laminae of sand and silt. Under this layer of clay, massive fine- and medium-grained sands are present that also contain fragments of sandstone. The upper part of the unit consists of loess that was reworked in a slope environment.

The Duraczów sediments come from two boreholes, ŁAG 1 and AAG 2, drilled in the Pleniglacial terraces (Fig. 6A). Both drillings reached the top of the Palaeozoic, at depths of $14.8 \mathrm{~m}$ and $22.5 \mathrm{~m}$, respectively. The sandy fluvial unit $\left(\mathrm{Fs}_{\mathrm{S}} \mathrm{P}_{\mathrm{VIII}}\right)$, from which the samples for mineralogical analyses were taken (at depths of $12.0 \mathrm{~m}$ and $19.8 \mathrm{~m}$ in drilling ŁAG1; and at $6.4 \mathrm{~m}$ and $12.4 \mathrm{~m}$ in $€ A G$ 2) overlies clays with fragments of the local Palaeozoic rocks (Fig. 6C).

The heavy minerals of 14 samples (numbers 68-81) from deposits at Maslowiec and of 4 samples (numbers 82-85) from deposits at the Duraczów site have been analysed (Table 5). 

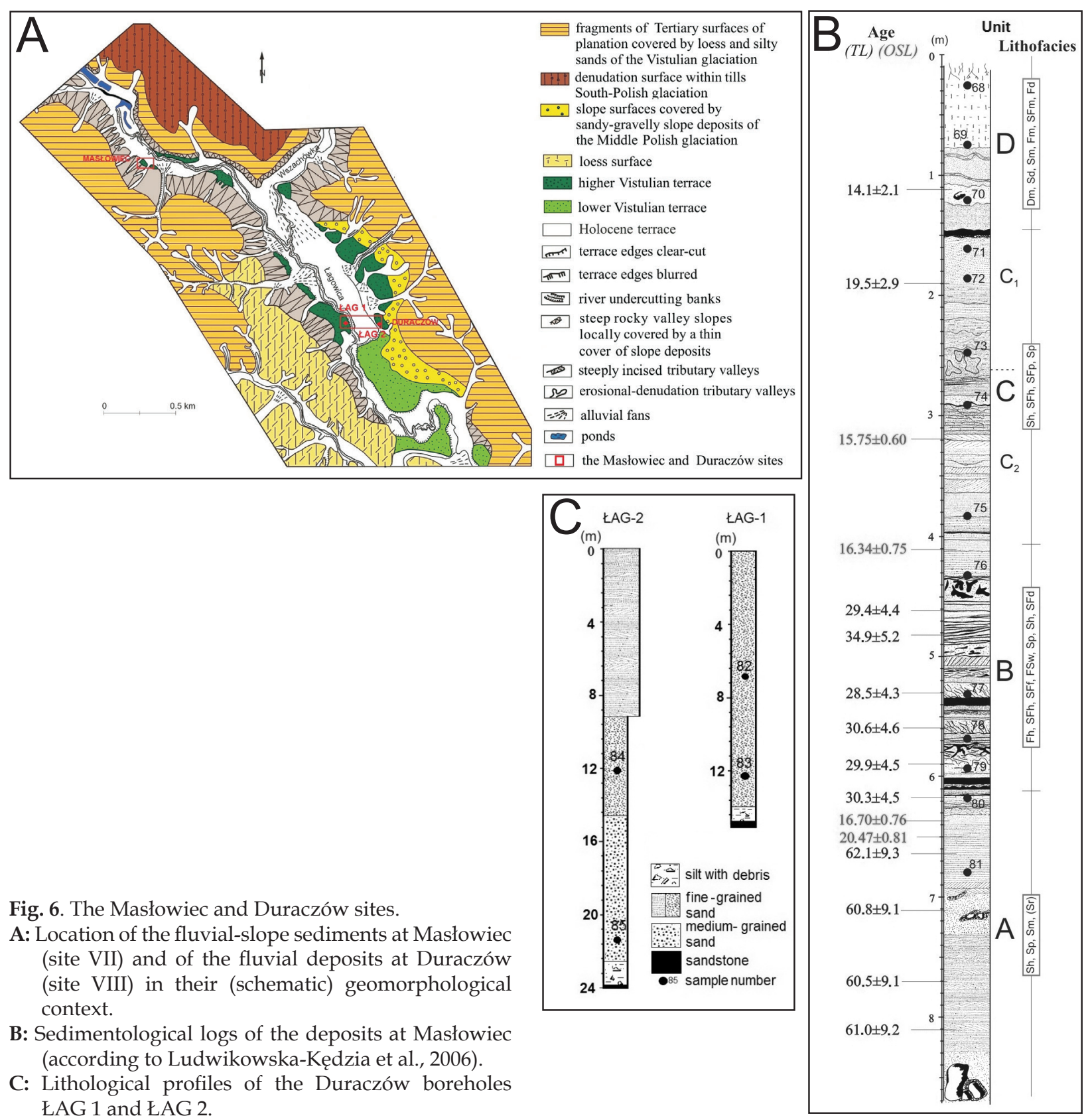

Fig. 6. The Masłowiec and Duraczów sites.

A: Location of the fluvial-slope sediments at Masłowiec (site VII) and of the fluvial deposits at Duraczów (site VIII) in their (schematic) geomorphological context.

B: Sedimentological logs of the deposits at Masłowiec (according to Ludwikowska-Kędzia et al., 2006).

C: Lithological profiles of the Duraczów boreholes ŁAG 1 and $Ł A G ~ 2$.

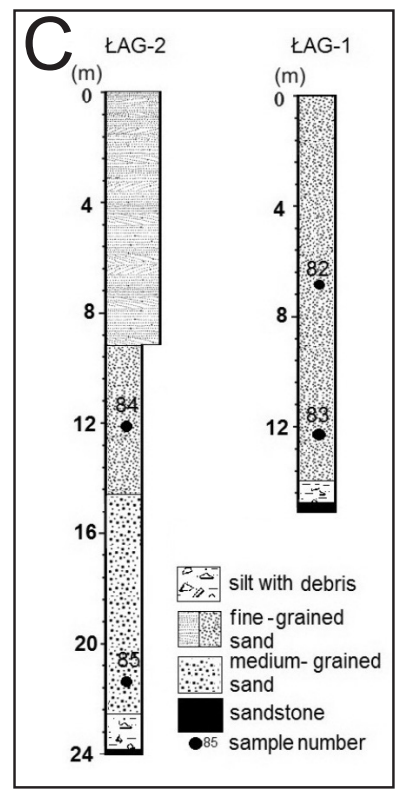

\subsection{The Górno site (IX)}

This site is located within the area of fluvio-periglacial accumulation (at 260-265 m a.s.1.), incised by shallow, small streams (Fig. 7A). The analysis focused on the bottom part of the sandy unit $\left(\mathrm{Fs}-\mathrm{EV}_{\mathrm{IX}}\right)$, which fills a vast, shallow depression in the Palaeozoic bedrock (Fig. 7B). The sands overlie silts and at places also clays containing fragments of Palaeozoic sandstones. The age of the unit was determined, using OSL, as early Vistulian (Fig. 7C).

The heavy minerals of 8 samples (numbers 86-93) from deposits at the Górno site have been analysed (Table 6).

\section{Heavy-mineral compositions}

\subsection{Weathered sandstone fragments (unit Wd-D ${ }_{\text {I-II }}$ )}

The heavy minerals in the weathered fragments of the Devonian sandstone at Huta Ko- 


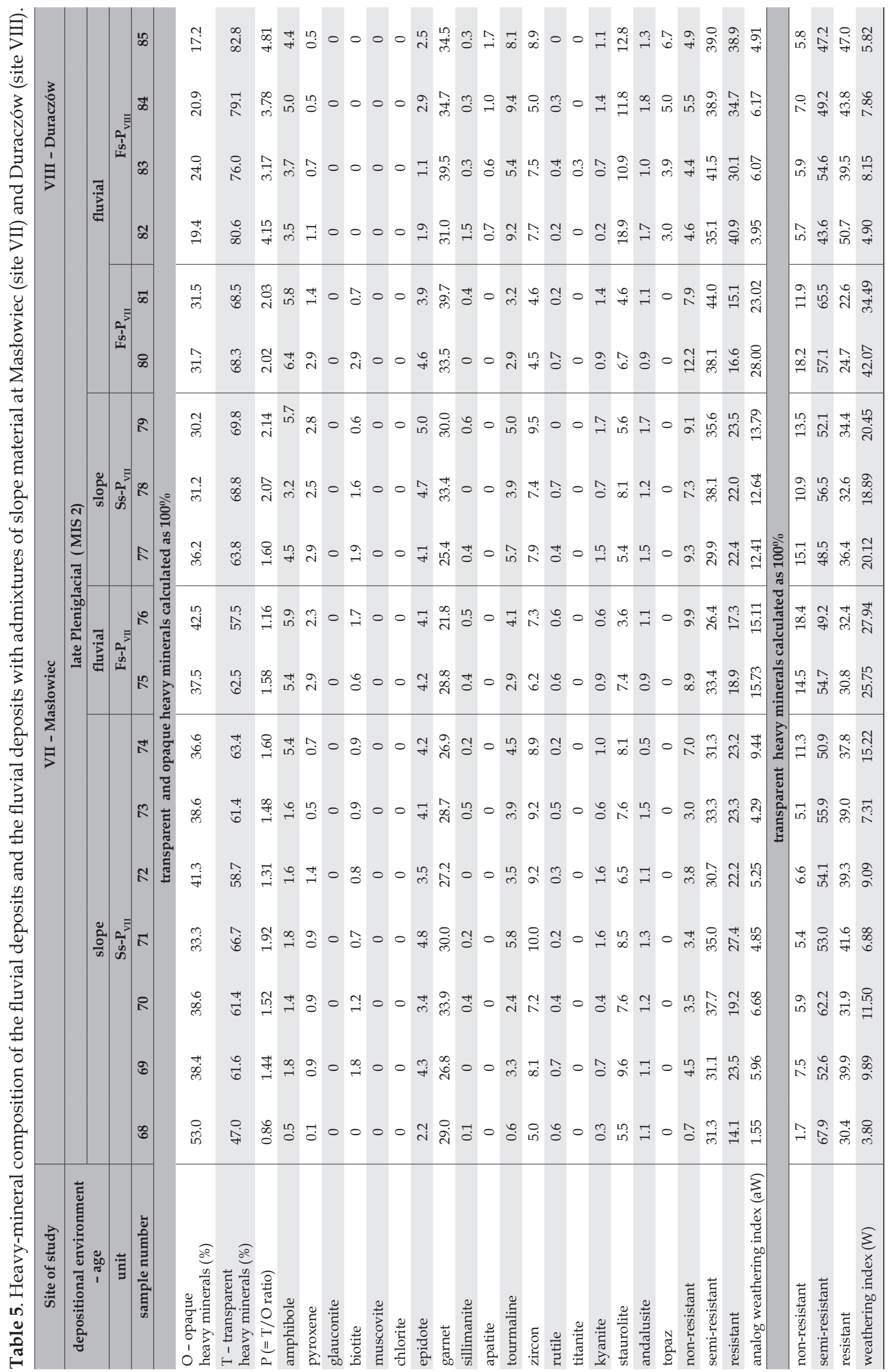



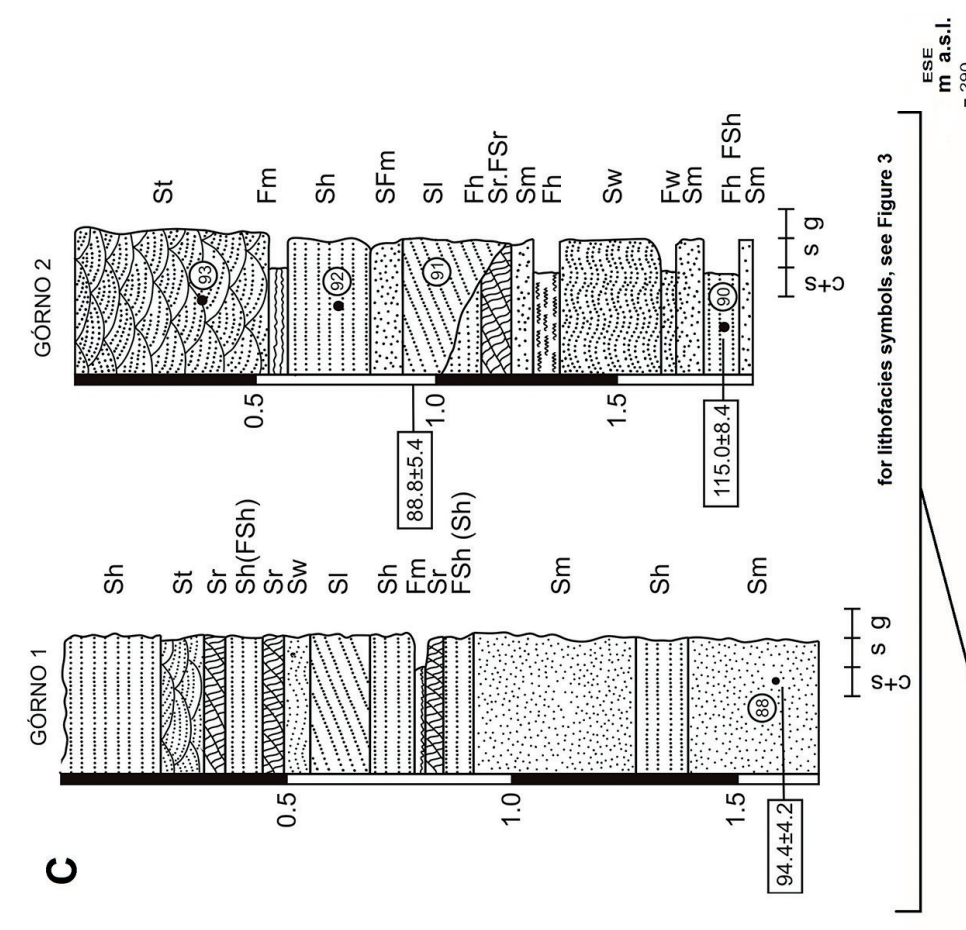

0

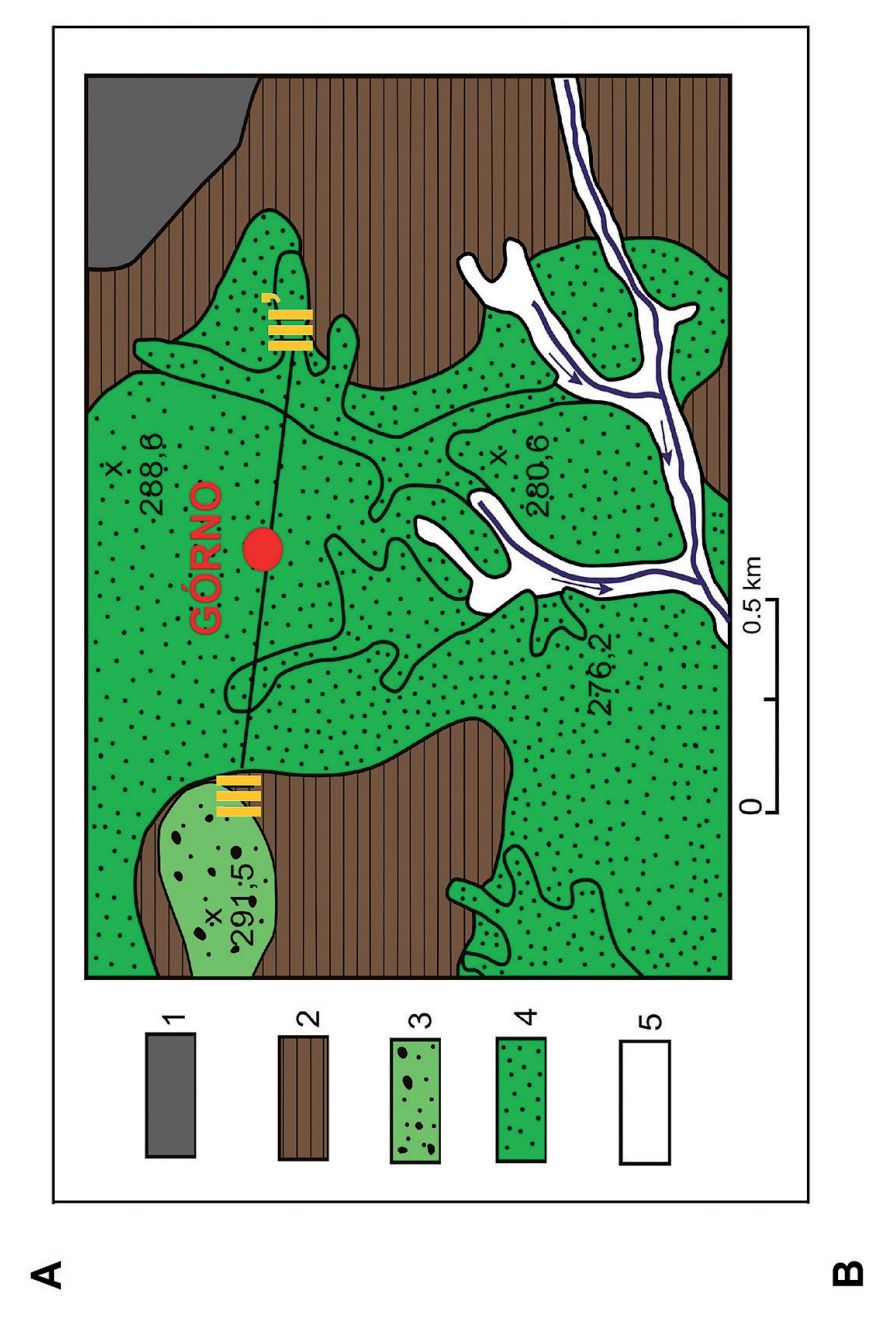

$<$

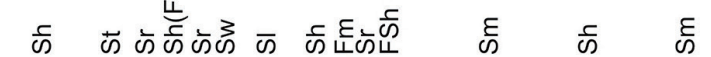

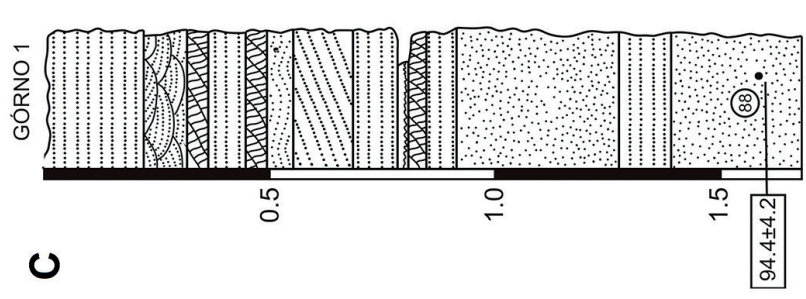

कृ̀

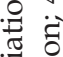

$\frac{\pi}{\infty} \cdot \frac{\pi}{0} \cdot \frac{\pi}{0}$

$\frac{60}{60}$

엉.

需

疋

焉艺

焉

पै

苋苋

के త్ర

동

즐

चै $\frac{0}{0}$

II

艾.

过

ฮี

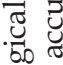

일

:

है

离. $\frac{\pi}{0}$

可

대욤

氠 它

卷苛㻤

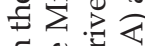

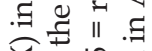

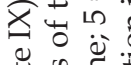

के क्जे

륭융

엉

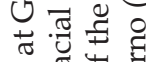

응

.

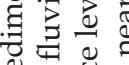

क

.

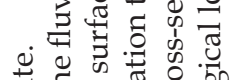

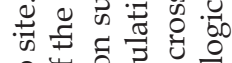

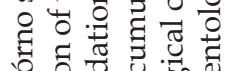

نิ

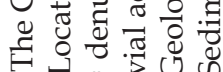

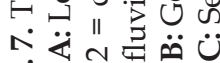

垔 
Table 6. Heavy-mineral composition of the fluvial deposits at Górno (site IX).

\begin{tabular}{|c|c|c|c|c|c|c|c|c|}
\hline Site of study & \multicolumn{8}{|c|}{ IX - Górno } \\
\hline $\begin{array}{c}\text { depositional environment } \\
\text { - age }\end{array}$ & \multicolumn{8}{|c|}{$\begin{array}{l}\text { fluvial deposits } \\
\text { early Vistulian (MIS 5d-b) }\end{array}$} \\
\hline unit & \multicolumn{8}{|c|}{ Fs-EV ${ }_{I X}$} \\
\hline sample number & 86 & 87 & 88 & 89 & 90 & 91 & 92 & 93 \\
\hline \multicolumn{9}{|c|}{ transparent and opaque heavy minerals calculated as $100 \%$} \\
\hline $\begin{array}{l}\mathrm{O} \text { - opaque } \\
\text { heavy minerals }(\%)\end{array}$ & 33.9 & 41.7 & 40.4 & 46.1 & 39.1 & 22.0 & 21.7 & 33.1 \\
\hline $\begin{array}{l}\mathrm{T} \text { - transparent } \\
\text { heavy minerals }(\%)\end{array}$ & 66.1 & 58.3 & 59.6 & 53.9 & 60.9 & 78.0 & 78.3 & 66.9 \\
\hline $\mathrm{P}(=\mathrm{T} / \mathrm{O}$ ratio $)$ & 1.95 & 1.40 & 1.48 & 1.17 & 1.56 & 3.55 & 3.61 & 2.02 \\
\hline amphibole & 9.3 & 4.2 & 6.6 & 5.7 & 5.7 & 12.0 & 13.3 & 7.2 \\
\hline pyroxene & 0.8 & 0.7 & 0.5 & 0.7 & 0.8 & 2.1 & 2.5 & 1.4 \\
\hline glauconite & 0 & 0 & 0 & 0 & 0 & 0.2 & 0 & 0 \\
\hline biotite & 0 & 0 & 0 & 0 & 0 & 0 & 1.1 & 0 \\
\hline muscovite & 0 & 0 & 0 & 0 & 0 & 0 & 0 & 0 \\
\hline chlorite & 0 & 0 & 0 & 0 & 0 & 0 & 0.2 & 0 \\
\hline epidote & 2.3 & 3.7 & 3.3 & 1.8 & 1.6 & 5.4 & 3.1 & 3.1 \\
\hline garnet & 3.6 & 3.3 & 4.7 & 6.1 & 3.5 & 2.1 & 1.6 & 4.4 \\
\hline sillimanite & 0.3 & 0.6 & 1.2 & 0.3 & 0.4 & 1.3 & 2.5 & 1.0 \\
\hline apatite & 3.0 & 1.9 & 2.1 & 2.3 & 2.2 & 2.5 & 2.5 & 1.4 \\
\hline tourmaline & 11.2 & 4.3 & 3.5 & 5.5 & 6.6 & 9.3 & 13.6 & 6.2 \\
\hline zircon & 13.7 & 23.5 & 23.1 & 16.8 & 23.1 & 22.1 & 18.1 & 18.6 \\
\hline rutile & 2.6 & 3.9 & 1.2 & 2.0 & 1.7 & 1.3 & 1.6 & 2.4 \\
\hline titanite & 0.3 & 0.6 & 0.6 & 0.6 & 0.3 & 0.4 & 0.4 & 0.5 \\
\hline kyanite & 3.8 & 3.0 & 2.0 & 1.7 & 3.2 & 4.5 & 4.7 & 4.3 \\
\hline staurolite & 10.9 & 7.0 & 8.6 & 8.8 & 8.8 & 11.4 & 9.5 & 12.8 \\
\hline andalusite & 0.8 & 1.2 & 1.1 & 0.6 & 1.7 & 1.6 & 2.0 & 1.7 \\
\hline topaz & 3.5 & 0.4 & 1.1 & 1.0 & 1.3 & 1.8 & 1.6 & 1.9 \\
\hline non-resistant & 10.1 & 4.9 & 7.1 & 6.4 & 6.5 & 14.3 & 17.1 & 8.6 \\
\hline semi-resistant & 9.2 & 9.5 & 11.3 & 10.5 & 7.7 & 11.3 & 9.7 & 9.9 \\
\hline resistant & 46.8 & 43.9 & 41.2 & 37.0 & 46.7 & 52.4 & 51.5 & 48.4 \\
\hline analog weathering index $(\mathrm{aW})$ & 1.99 & 1.06 & 1.95 & 1.82 & 1.07 & 3.08 & 3.22 & 1.76 \\
\hline \multicolumn{9}{|c|}{ transparent heavy minerals calculated as $100 \%$} \\
\hline non-resistant & 15.0 & 8.5 & 11.9 & 11.9 & 10.7 & 18.3 & 22.0 & 12.8 \\
\hline semi-resistant & 14.3 & 16.2 & 19.0 & 19.5 & 12.7 & 14.4 & 12.3 & 14.8 \\
\hline resistant & 70.7 & 75.3 & 69.1 & 68.6 & 76.6 & 67.3 & 65.7 & 72.4 \\
\hline weathering index $(\mathrm{W})$ & 3.03 & 1.83 & 3.27 & 3.38 & 1.77 & 3.92 & 4.12 & 2.62 \\
\hline
\end{tabular}

szary (site 1) contain three times more opaque $(75.6 \%)$ than transparent $(24.6 \%)$ minerals (Table 1, Fig. 8A). At Koszary (site 2), however, the proportions of transparent $(52.1 \%)$ and opaque $(47.8 \%)$ minerals are roughly the same (Table 2 , Fig. 8A). The values of the proportionality index $(\mathrm{T} / \mathrm{O})$ are 0.32 and 1.08 , respectively, for the sites (Tables 1-2).

The transparent minerals contain mainly resistant minerals, mostly tourmaline, zircon, rutile, titanite and kyanite (Tables 1-2, Fig. 8), forming $Z>M>T$ (epi) and $T>Z$ (rut,mus) assemblages. They contain a significant percentage of micas, as well as epidote, and trace amounts of pyroxene and glauconite, but no garnet. The values of the analog weathering indexes are low (0.75 and 0.03 , respectively) (Tables 1-2, Fig. 8C). For comparison: the calculated weathering indexes, $\mathrm{W}$, are also low (3.03 and 0.06, respectively) (Tables 1-2, Fig. 8D-F).

\subsubsection{Interpretation}

The differences in the mineralogical composition of the weathered fragments of the Devonian sandstones may primary result from different conditions. The heavy minerals belong mainly to the group of resistant minerals, inset free during the weathering, they contributed to the weathered material that reworked and modified during successive sedimentation cycles. The analyses confirm the petrographical 

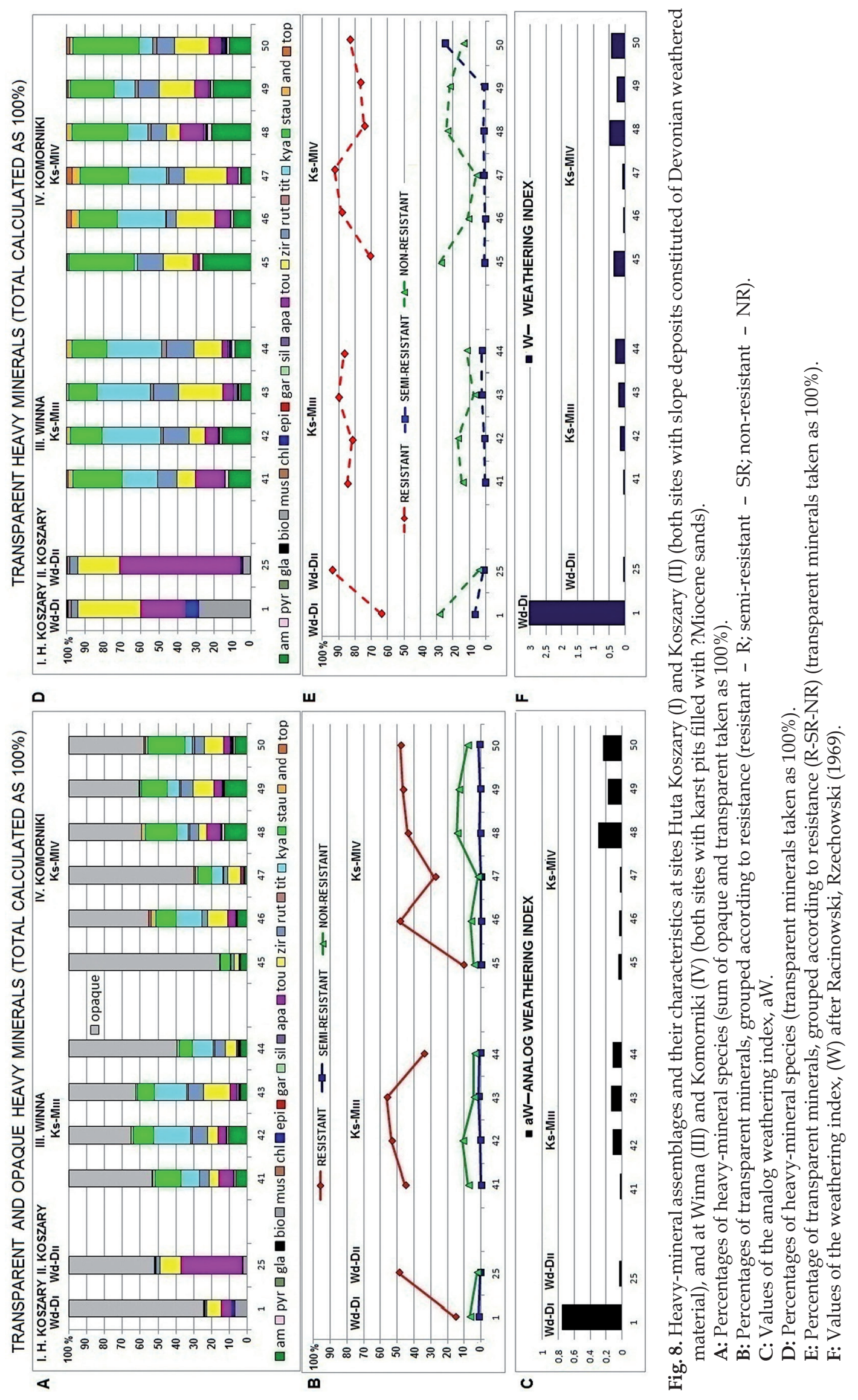
studies of Devonian sandstones by Harapińska-Depciuch (1957) and Tarnowska (1971).

\subsection{Karst pit (unit $\mathrm{Ks}-\mathrm{M}_{\mathrm{III}-\mathrm{IV}}$ )}

The heavy minerals from ten samples of the sandy unit filling the karst pits in the Devonian dolomites at Winna (III) and Komorniki (IV) were identified. The transparent minerals range from $15.3 \%$ to $39.5 \%$, and from $53.3 \%$ to $65.3 \%$, respectively (Table 3 , Fig. $8 \mathrm{~A}$ ). The values of the proportionality index $(\mathrm{T} / \mathrm{O})$ are 0.18-0.65 and 1.14-1.88, respectively, for both sites) (Table 3). They mostly consist of resistant minerals, i.e. staurolite, kyanite, zircon, tourmaline, rutile and andalusite (Table 3, Fig. $8 \mathrm{~B})$. Among the non-resistant minerals (1.8$11.3 \%)$, the most important are amphiboles and pyroxenes. Semi-resistant minerals are insignificant. The values of the analog weathering index, $\mathrm{aW}$, are very low and range from 0.02 to 0.29 (Table 3, Fig. 8C), whereas those of the weathering index, $\mathrm{W}$, are $0.05-0.49$ (Table 3, Fig. 8D-F). The minerals form $K>S T>Z$ (rut,amp,tou) and ST $>$ AM $>Z$ (kya,tou,rut) assemblages.

\subsubsection{Interpretation}

The deposits include two prominent groups of minerals; one includes almost exclusively minerals with a high resistance to chemical weathering, whereas the other contains mainly non-resistant ones, like in sandy deposits of karst pits in the SE part of the Sandomierska Upland (Mycielska-Dowgiałło, 1965). The first mineral group is an indicator of a warm and moist climate (Barcicki et al., 1988). It may be assumed that denudation and erosion of the sedimentary cover provided only a very small number of heavy-mineral species. The second group of minerals is ascribed to the denudation of the cover of the glacial deposits which topographically mask the karst pits.

\subsection{Glacial deposits (unit $\mathrm{Gt}-\mathrm{O}_{\mathrm{v}-\mathrm{VI}}$ )}

Transparent minerals (60.0-61.5\%) prevail in the samples of tills at Mąchocice (site V) and in the two till samples (54.7-58.2\%) collected at Napęków (site VI) (Table 4, Fig. 9A), whereas opaque minerals predominate $(64.4-81.6 \%)$ in the two till samples from Napęków (site VI). The values of the proportionality index $(\mathrm{P})$ are 1.5-1.65 at the Mąchocice site and 0.23-1.39 at the Napęków site (Table 4).

Semi-resistant minerals (8.0-29.8\%) prevail in the group of transparent minerals (Table 4, Fig. 9B). The proportion of non-resistant minerals $(6.8-17.6 \%)$ is comparable with that of the resisting ones, especially at the Mąchocice site. Qualitatively, the deposits are dominated by garnet and amphibole, accompanied by zircon, kyanite, staurolite and pyroxene; they form the following order: $G>A M>Z$ (epi,sta,kya), Z>G>AM (epi,rut), G>AM (zir,kya,sta,pyr). The values of the analog weathering index, $\mathrm{aW}$, are in the range of 14.10-35.47 (Table 4, Fig. 9C), and the weathering index, $W$, is 39.083.74 (Table 4, Fig. 9D-F).

\subsubsection{Interpretation}

The mineral assemblage is characteristic of glacial tills, with the dominant minerals form the order G>AM>Z (Racinowski, 2008). Biotite, regarded in this region as typical of glacial tills (Racinowski, 2008), occurs nevertheless only sporadically in the deposits. However, the enrichment with some resistant minerals (zir, kya, sta), typical of older bedrock, indicates a local (i.e. inside the Holy Cross Mountains) source of weathered material. The mineralogical composition of the clays resembles the clay composition in the nearby Wilkowska Valley (Kowalski et al., 1979), but it lacks biotite and contains a significant amount of kyanite.

\subsection{Slope deposits (till succession)}

\subsubsection{Unit St- $\mathrm{L}_{\mathrm{II}}$}

Opaque minerals prevail (55.3-60.3\%) in the two samples of from Koszary (site II) (Table 2, Fig. 9A) and the value of the proportionality index, $\mathrm{P}$, is $0.64-0.78$ (Table 2). The transparent minerals are dominated by zircon (24.7-27.7\%) and staurolite (5.0-5.2\%). They are accompanied by other resistant minerals, viz. tourmaline, kyanite and andalusite. The semi-resistant 


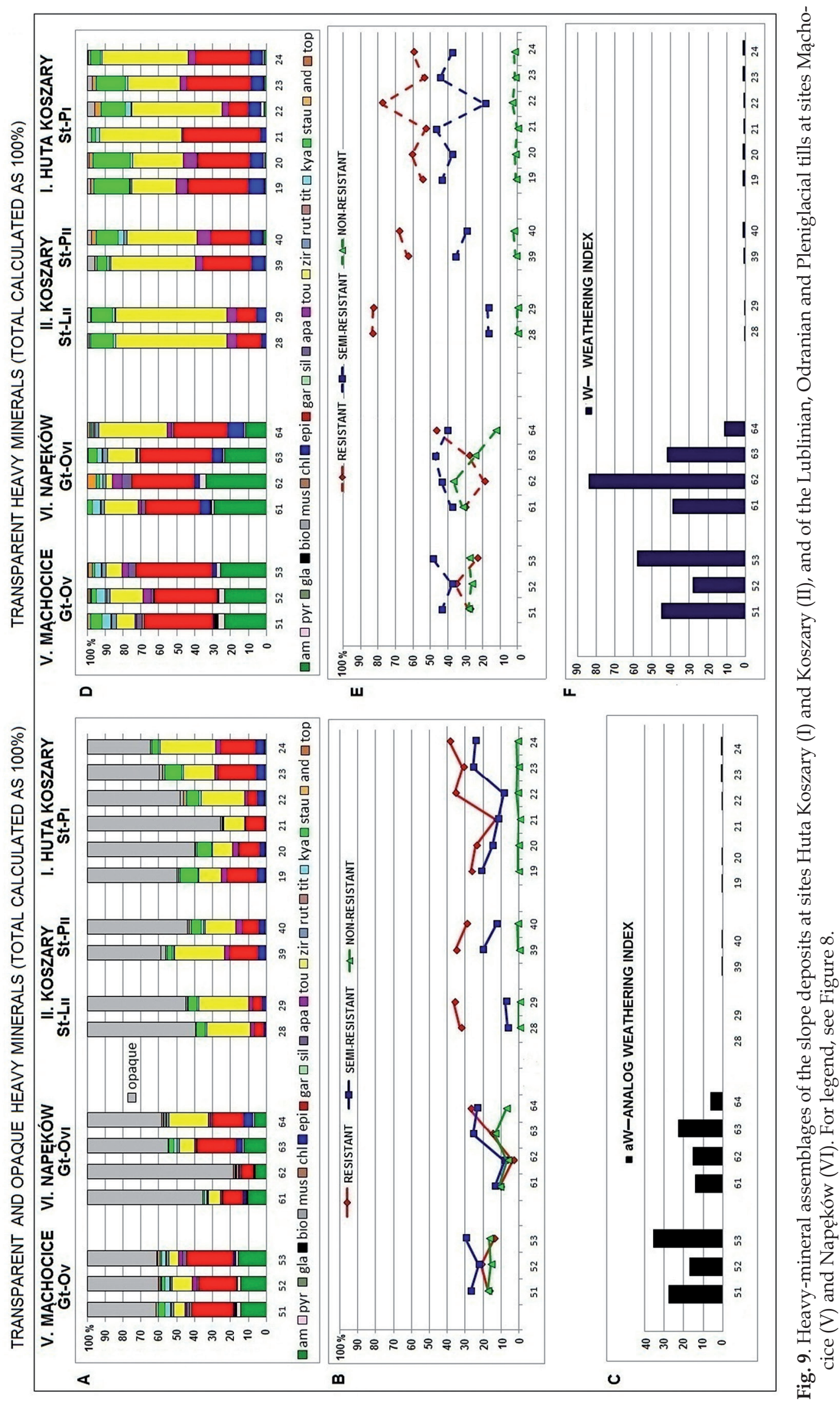


minerals include garnet (5.2-5.4\%) and epidote (1.1-2.3\%) (Table 2, Fig. 9B). Non-resistant minerals are absent, so the analog weathering index, aW, and the weathering index, $\mathrm{W}$, cannot be calculated (Table 2, Fig. 9D-F). The dominant minerals occur in the order $\mathrm{Z}$ (gar,sta,tou).

\subsubsection{Interpretation}

The mineral composition resembles that of the Ss- $\mathrm{K}_{\mathrm{II}}$ (Table 2) unit underneath. Unit Ss$\mathrm{K}_{\mathrm{II}}$ was formed by solifluction of material that must have included not only sands from this unit, but also loess.

\subsubsection{Unit St-P}

Six samples of Pleniglacial diamictons sampled at Huta Koszary (site I) and two samples from Koszary (site II) were analysed (Tables 1-2, Fig. 9A). Opaque minerals (51.0-75.32\%) prevail in the five samples of the periglacial clays, whereas transparent minerals (56.2$64.5 \%$ ) predominate in the three samples (Tables 1-2). The values of the proportionality index, $\mathrm{P}$, are $0.33-0.96$ and $1.28-1.83$, respectively (Tables 1-2). Resistant minerals (13.1$38.8 \%)$, represented by zircon, staurolite and tourmaline, prevail among the transparent minerals (Tables 1-2, Fig. 9A-B). The semi-resistant minerals are garnet and epidote. The dominant minerals form the assemblages $Z>G$ (sta,epi,tou) and G>Z (sta,epi). The analog weathering index ranges from 0.29 to 0.82 (Tables 1-2, Fig. 9C), and the weathering index from 0.51 to 1.32 (Tables 1-2, Fig. 9D-F).

\subsubsection{Interpretation}

Compared with the clay from the Krznanian interglacial, the Pleniglacial tills contain more epidote. The younger unit contains an increasing amount of non-resistant and of semi-resistant minerals (garnet). The slope deposits of the Bieliny range were isolated, and were not affected by the glacigenic processes connected with the Odranian glaciation that took place at the bottom of the Kielce-Łagów Valley. This explains their similar mineralogical composition.

\subsection{Fluvioglacial deposits (unit FGs- $\mathrm{O}_{\mathrm{v}-\mathrm{vI}}$ )}

Six fluvioglacial samples from Mąchocice (site V) and two from Napęków (site VI) were analysed for their heavy minerals. The deposits of both sites have a diverse mineral composition, but a similar content of non-transparent $(32.8-52.0 \%)$ and transparent minerals (48.0-67.2\%) (Table 4, Fig. 10A). The values of the proportionality index, $\mathrm{P}$, are $0.92-1.28$ (Table 4). Only one sample is different: the transparent minerals prevail, and the proportionality index is 2.05. Among the transparent minerals, semi-resistant species dominate, i.e. garnet with epidote and apatite (Table 4, Fig. 10B). The heavy minerals contain a large proportion of non-resistant species (amphiboles and pyroxenes) and a smaller proportion of resistant minerals (mainly zircon, together with staurolite, tourmaline, and kyanite). They occur in the order G>AM (zir,sta), AM (gar,kya,pyr), G>Z (amp,sta). The analog weathering index ranges from 16.63 to 26.05 (Table 4, Fig. 10C), and the weathering index ranges from 31.74 to 45.95 (Table 4, Fig. 10D-F).

\subsubsection{Interpretation}

The mineral composition is typical of sandy/ gravelly fluvioglacial deposits as present all over Poland (Racinowski, 2008), i.e. G>AM, $\mathrm{G}>\mathrm{Z}$. These fluvioglacial deposits became undoubtedly a source material for younger fluvial sediments. The weathering value is similar to that of fluvioglacial deposits from the western part of the Holy Cross Mountains (Radłowska \& Mycielska-Dowgiałło, 1972).

\subsection{Slope deposits (sandy successions)}

\subsubsection{Unit Ss-K}

The heavy minerals in the two samples of the periglacial unit consisting of sandy deposits at Koszary (site II) contain hardly more opaque than transparent minerals $(53.4 \%$ vs. $46.6 \%$ for site I, and $54.2 \%$ vs. $45.8 \%$ for site II) (Table 2, Fig. 11A). The values of the proportionality index are $0.84-0.87$ (Table 2). Non-resistant transparent minerals are lacking (Table 2, Fig. 11B), so the analog weathering index 

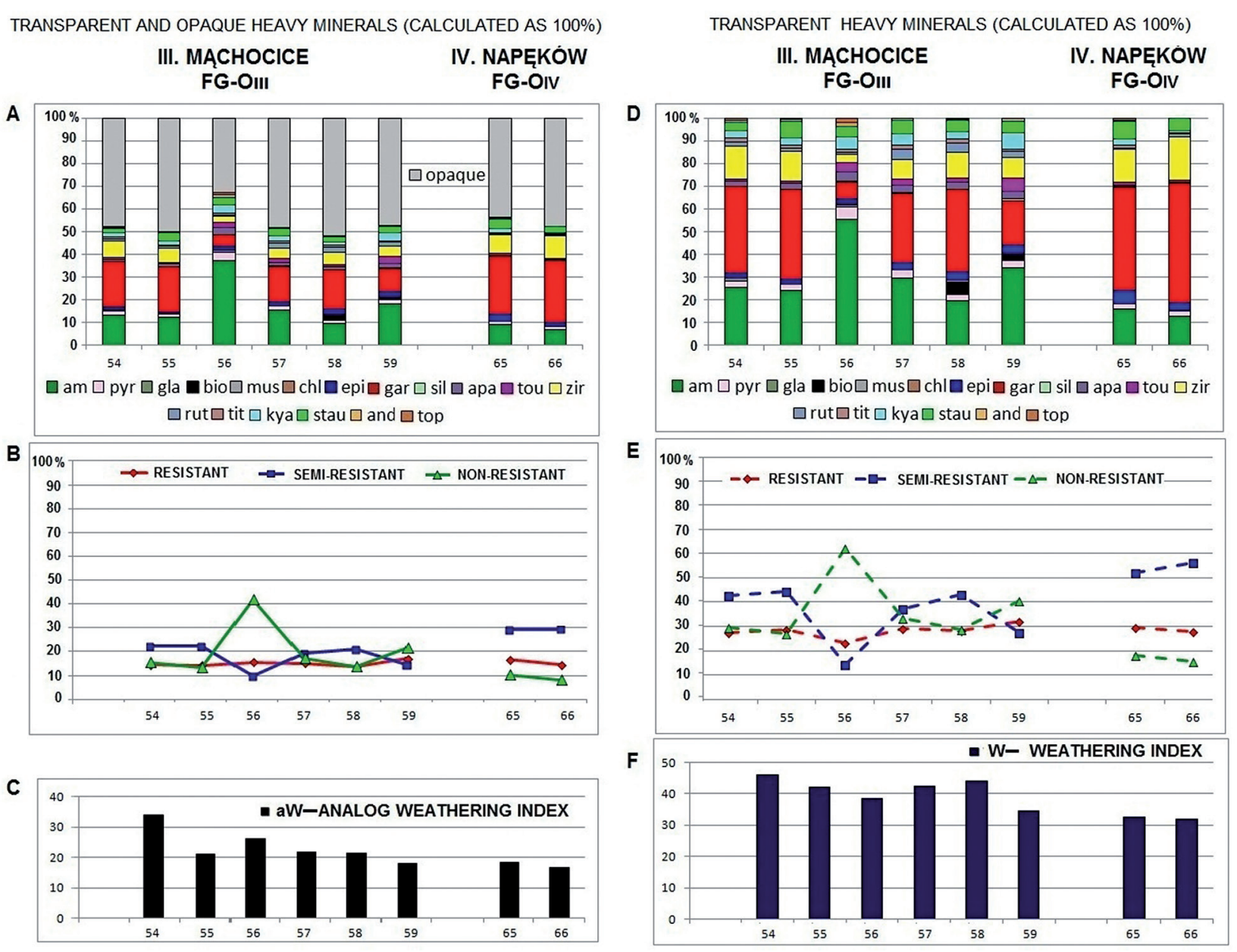

Fig. 10. Heavy-mineral assemblages of the Odranian fluvioglacial deposits at Mąchocice (V) and Napęków (VI). For legend, see Figure 8.

and the weathering index cannot be calculated (Table 2, Fig. 11C-F). Resistant minerals are the most prominent, with zircon, followed by staurolite, rutile, tourmaline and kyanite. Garnet and epidote represent the semi-resistant minerals. The dominant minerals occur in the order Z (sta,gar,epi).

\subsubsection{Interpretation}

The mineral composition indicates that the deposit was strongly modified by secondary destructive processes, mostly chemical weathering but also washing. The presence of the zircon-staurolite-tourmaline assemblage implies that weathered Palaeogene-Neogene fragments were present in this unit (with properties as at the Winna and Komorniki sites).

\subsubsection{Unit Ss- $\mathrm{O}_{\mathrm{I}}$}

The heavy minerals from the Huta Koszary (site I) and Koszary (site II) sites were identified for 15 samples of Odranian slope sediments. The opaque minerals $(68.4-79.7 \%)$ prevail in the five samples (Table 1). In the other samples, the transparent minerals (50.5-63.0\%) dominate. The values of the proportionality index are $0.25-0.95$ for the five opaques-dominated samples and 1.06-1.70 for the other samples (Table 1).

These slope deposits are characterised by a relatively low number of heavy-mineral species (Table 1, Fig. 11). The percentages of zircon and garnet are high. Staurolite and epidote are also common, but tourmaline, andalusite and kyanite occur only in low quantities. The content of the remaining heavy minerals, i.e. silli- 

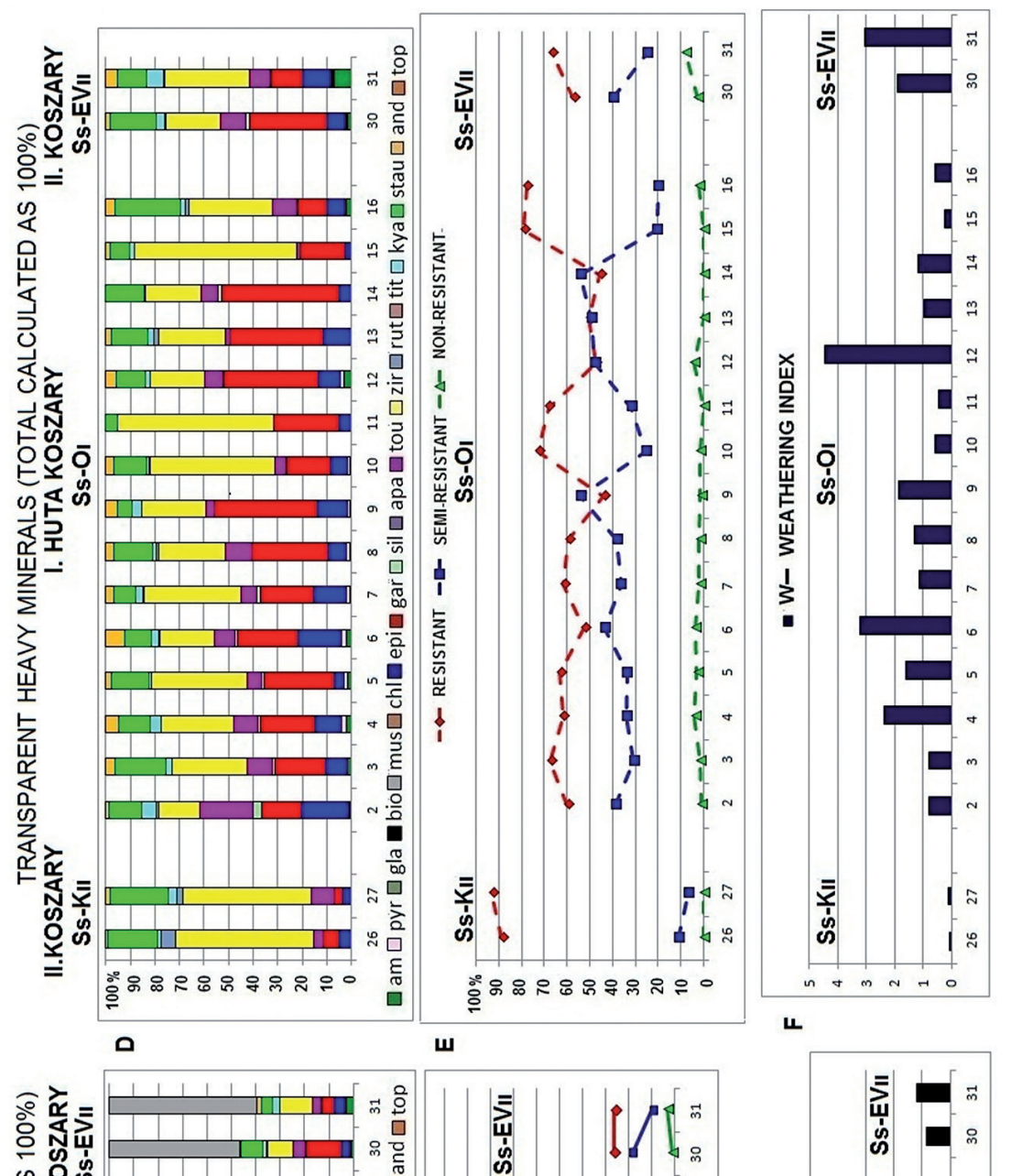

4
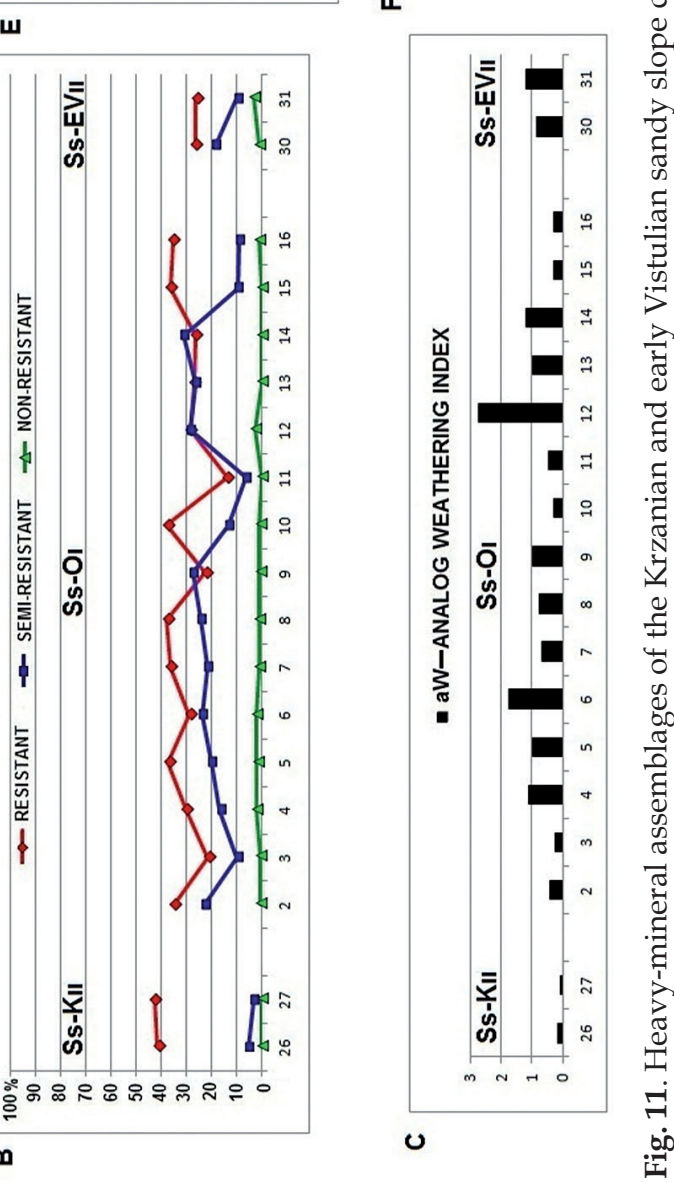
manite, rutile, amphibole and pyroxene, is low. Biotite and chlorite are absent.

With respect to the minerals' resistance to mechanical abrasion and chemical weathering, the sediments contain mostly resistant minerals (42.9-76.4\%) (Table 1, Fig. 11). The semi-resistant minerals occur in only slightly lower percentages and are even more numerous in three samples. Non-resistant minerals make up only a few percent. The dominant minerals typically occur as $Z>G, G>Z$ (sta,epi,tou). The value of the analog weathering index is $0.23-2.71$ (Table 1, Fig. 11C), and the weathering index is $0.56-4.44$ (Table 1 , Fig. 11D-F). The values of the weathering indexes in the four samples could not be calculated, because non-resistant transparent minerals are lacking (Table 1 ).

\subsubsection{Interpretation}

The material of this unit has a long history: it contains mainly minerals which are resistant and semi-resistant to mechanical abrasion and chemical weathering, and only a small proportion of non-resisting minerals; there are no minerals from the mica group, there is a high percentage of opaque minerals, and most grains show a well-developed coating. This indicates involvement in several depositional/erosional cycles, as well as intensive chemical weathering and physical attrition. This is supported by a low analog weathering index as well as a low weathering index. It is interesting that the deposits are dominated by a zircon/garnet assemblage, two minerals with a high mass.

The Cambrian rocks that surround the Kielce-Łagów Valley are also a possible source of minerals such as garnet, zircon, tourmaline and rutile (Radziszewski, 1928). This assemblage is also known from tidal environments, especially at the edge of the tidal range (Komar et al., 1989). A similar assemblage has been found in certain formations filling surface karst forms of the Cracow upland (Krysowska-Iwaszkiewicz, 1974), where they were interpreted as fluvioglacial. The relatively high content of garnet might be due to aeolian activity leading to relative enrichment with these minerals (Mycielska-Dowgiałło, 1995, 2001; Barczuk \& Mycielska-Dowgiałło, 2001).

\subsubsection{Units Ss-EV $\mathrm{II}_{\mathrm{II}}$ and Ss-P $\mathrm{P}_{\mathrm{I}-\mathrm{II}}$}

The heavy-mineral composition of the sandy periglacial slope deposits at Huta Koszary (site I) and Koszary (site II) was analysed for 11 samples. Opaque minerals prevail in the early Vistulian deposit (53.9-61.0\%) and in the three Pleniglacial samples (52.9-55.7\%) (Tables $1-2$, Figs 11-12). The value of the proportionality index is $0.63-0.90$ (Tables 1-2). In the other Pleniglacial samples, the transparent minerals (52.70-66.0\%) prevail. The assemblages are dominated by semi-resistant minerals, mostly garnet and, in smaller quantities, epidote; resistant minerals are represented by zircon, staurolite and tourmaline (Tables 1-2, Figs 11-12B). The dominant transparent minerals are present as $Z>G ; G>Z$ (sta,epi,tou), G (zir, sta), ST>Z (gar,tou). The analog weathering index ranges from 0.21 to 6.20 (Tables 1-2, Figs $11-12 \mathrm{C}$ ) and the weathering index from 0.46 to 9.35 (Tables 1-2, Figs 11-12D-F).

\subsubsection{Interpretation}

The assemblage largely resembles that of the sandy Odranian glacigenic unit in the upper part of the less inclined slope under the steep-sloping Devonian sandstones of the Bieliny range; it is also similar to that of older Middle-Polish complexes at the study site. Thus it can be assumed that, in general, the Middle-Polish complex is the source of the Pleniglacial unit. The mineralogical composition of the older deposits was gradually modified, primarily as a result of periglacial denudation, weathering and aeolian erosion; the last process was responsible for the relative enrichment with garnet. The possibility that denudation transformed the older slope deposits into younger ones in the Holy Cross Mountains has earlier been put forward by Klatka (1962).

\subsubsection{Unit Ss-P}

Ten samples of the slope deposits at Masłowiec (site VII) were analysed. The transparent minerals (58.7-69.8\%) are more frequent than opaque species (30.2-41.3\%), except for one sample (Table 5, Fig. 12A). The value of the proportionality index is 1.31-2.07; for one sample it is only 0.86 (Tables 1-2). Among the transparent minerals, semi-resistant species, 

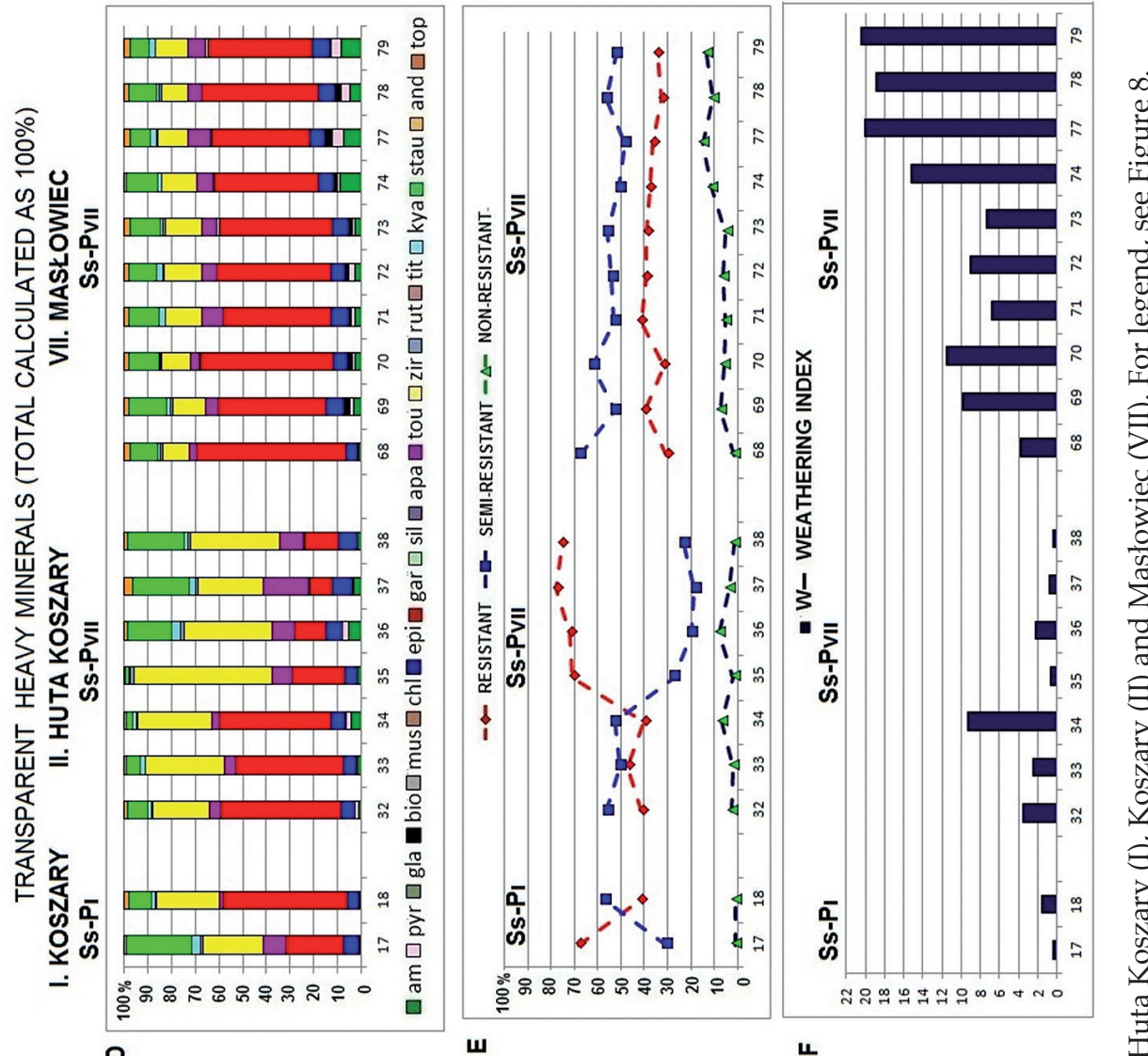

ㅎํㅇ
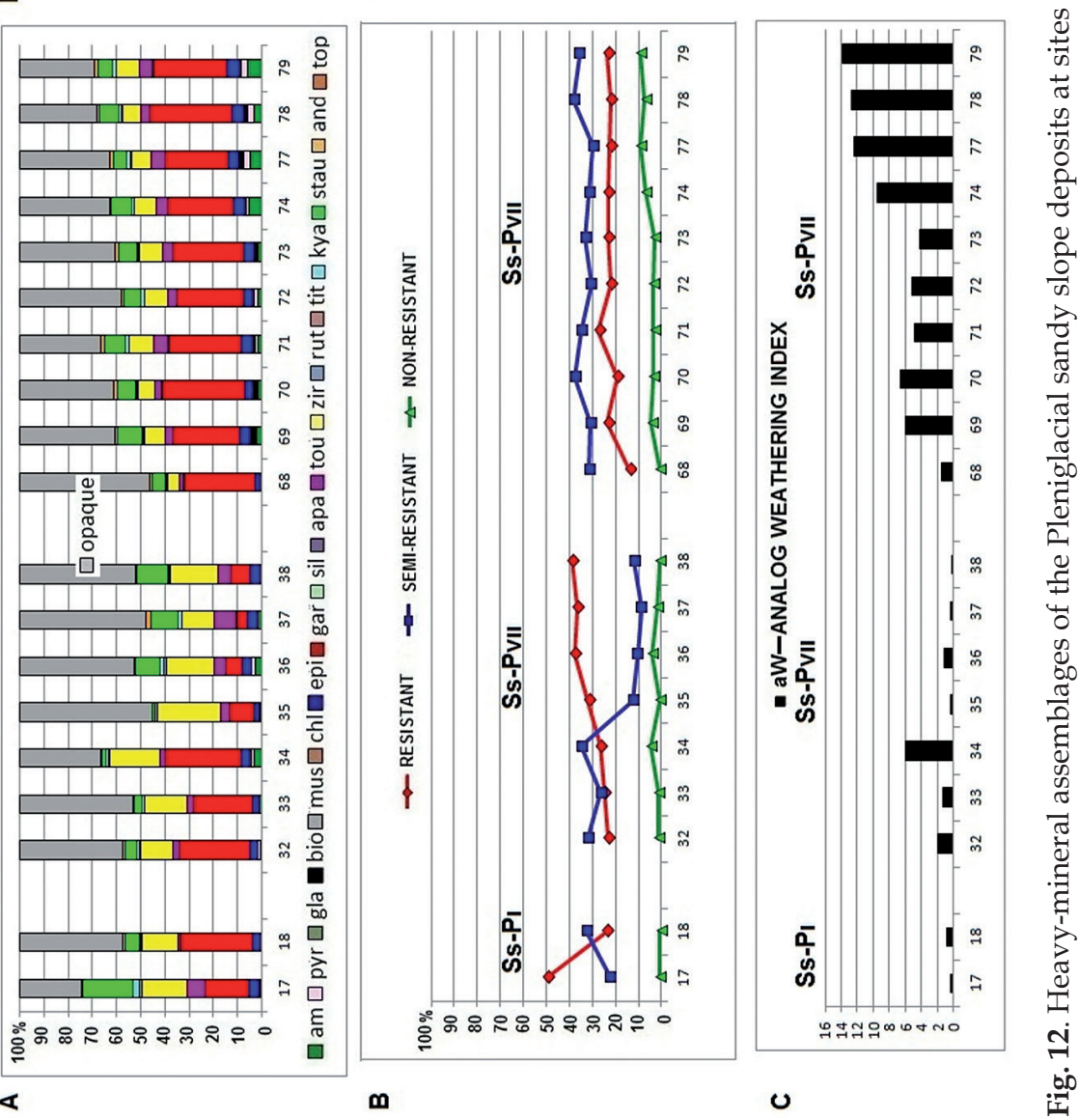
mostly garnet, and to a lesser extent epidote, dominate, always with a large proportion of the resistant minerals zircon, staurolite and tourmaline, but also with amphibole, pyroxene and biotite (Table 5, Fig. 12). The analog weathering index ranges from 4.29 to 13.79 (Table 5, Fig. 12C) and the weathering index from 6.88 to 20.45 (Table 5, Fig. 12D-F). The deposits have a characteristic composition with few species: G>ST (zir,epi) or G>Z (sta,epi).

\subsubsection{Interpretation}

The exceptionally large proportion of garnets indicates strong aeolisation. The high percentage of resistant minerals, on the other hand, may indicate that the parent material was reworked numerous times and consisted mainly of weathered fragments of local Palaeozoic rocks (Michniak, 1969) and the Palaeogene-Neogene cover. One cannot exclude either the possibility of the glacial and fluvioglacial cover as a source, as this cover occurs on the surface of hill tops and rocky slopes of the valley. These elements were strongly denudated and eroded under the periglacial conditions that persisted in this part of the Holy Cross Mountains for a long time-span. These deposits were repeatedly reworked, eventually becoming part of newly formed fluvial deposits. These fluvial processes led to a relative enrichment in garnet (cf. Mycielska-Dowgiałło, 1978; Florek et al., 1987; Mycielska-Dowgiałło \& Rutkowski, 1995; Ludwikowska-Kędzia, 2000). A similar process of relative enrichment in garnet is known from the aeolian environment (Mycielska-Dowgiałło, 1995, 2001), which is also shown by a large content of garnet in the upper part of series D (Unit Ss-P $\left.{ }_{\mathrm{VII}}\right)$.

\subsection{Fluvial deposits}

\subsubsection{Unit Fs-EV}

Transparent minerals prevail (53.9-78.3\%); among them, minerals resistant to weathering dominate the fluvial deposits at Górno (site IX) (8 samples) (Table 6, Fig. 13A-B). The value of the proportionality index ranges from 1.17 to 3.61 (Table 6). They are represented by zircon, staurolite, tourmaline, kyanite and apatite. The proportions of the non-resistant minerals and of the semi-resistant minerals are roughly the same. In the former group, amphibole is the most common, whereas garnet is the most common in the latter. The dominant minerals can be ranked as $\mathrm{Z}>\mathrm{ST}>\mathrm{T}$ (amp,kya). The value of the analog weathering index is low and ranges from 1.06 to 3.22 (Table 6, Fig.13C) and the weathering index is 1.77-4.12 (Table 6, Fig. 12D-F).

\subsubsection{Interpretation}

The mineral composition strongly resembles that of the slope covers of the Bieliny range, but most probably also that of other nearby slope deposits. The short transportation of the slope material did not significantly change the mineral composition, which is dominated by resistant minerals. The occurrence of staurolite and kyanite indicates that Palaeogene-Neogene material must be involved. The amphibole may be derived from glacial material.

\subsubsection{Unit Fs- $\mathrm{P}_{\mathrm{V}-\mathrm{VI}}$}

Two samples of fluvial deposits were analysed, one from Mąchocice (site V) and a second from Napęków (site VI). The deposits are characterised by an uncommonly high proportion of transparent minerals (71.0-72.9\%) and minerals from the semi-resistant group, mainly garnet (Table 4, Fig. 13A-B). The content of this mineral is so high that there are hardly any other heavy minerals; zircon, followed by staurolite, kyanite and tourmaline are the most important resistant minerals. The non-resistant minerals are represented by amphibole. The dominant minerals can be ranked as G (zir,amp,sta) G>Z (amp,sta,tou). The analog weathering index ranges from 12.62 to 19.55 (Table 4, Fig. 13C) and the weathering index is 17.17-27.29 (Table 6, Fig. 12D-F).

\subsubsection{Interpretation}

The mineral composition resembles that of the fluvioglacial deposits (unit FGs-O $\mathrm{V}_{\mathrm{VII}}$ ). The latter most probably form the source material for these fluvial deposits, which were strongly affected by aeolian processes under periglacial conditions. 

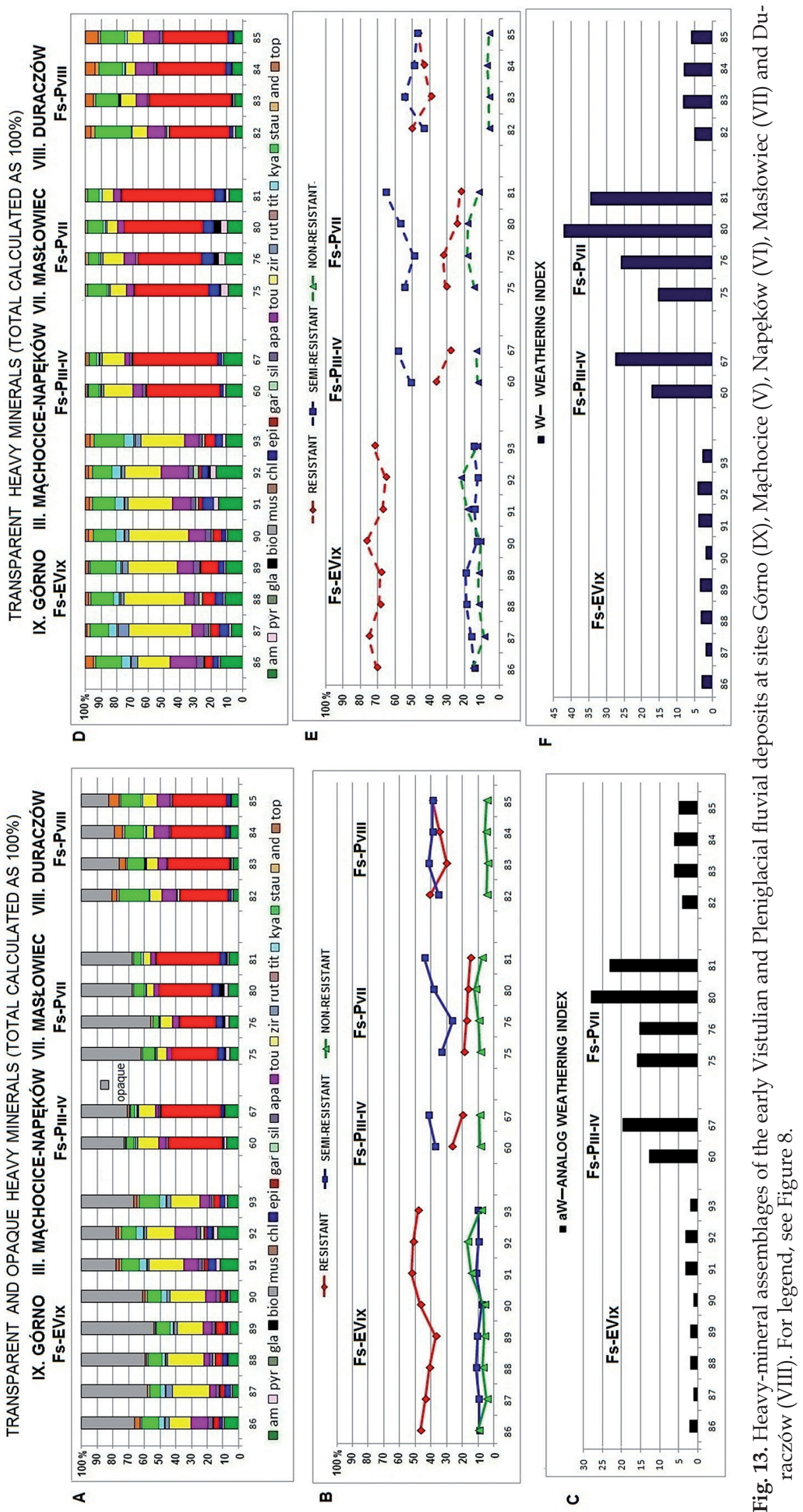


\subsubsection{Unit Fs-P $P_{\text {VII-VIII }}$}

In the heavy-mineral composition of the fluvial deposits at Masłowiec (site VII) and Duraczów (site VIII) (four samples from each site), transparent minerals prevail (57.5-82.8\%); their proportion is particularly high at the Duraczów site (76.0-82.8\%). The values of the proportionality index range from 1.16 to 4.81 (Table 5). The heavy-mineral composition of the fluvial deposits is dominated by semi-resistant minerals, mainly garnet, with epidote as second (Table 5, Fig. 13A-B). The proportion of resistant minerals (mainly staurolite, zircon and tourmaline, with lesser amounts of andalusite, topaz and sillimanite) at Masłowiec is only half that of Duraczów, where the content of resistant minerals is also more diverse (with apatite and topaz). The unit contains a relatively small proportion of non-resistant minerals (amphibole, pyroxene and mica, and at Duraczów also biotite. The transparent dominant minerals can be ranked as $\mathrm{G}$ (zir,sta,amp) and G>-ST (tou,zir). The analog weathering index of the deposits at Masłowiec ranges from 15.11 to 28.0, and at Duraczów from 3.95 to 6.17 (Table 5, Fig. 13C). The weathering index ranges from 25.75 to 42.07 , and from 4.90 to 8.15 , respectively, for both sites (Table 5, Fig. 13D-F).

\subsubsection{Interpretation}

The heavy minerals indicate a relatively high age of the fluvial deposits. The source material must consequently also be 'old', i.e. at least partly consisting of weathered local sedimentary rocks (Michniak, 1969) that were subsequently repeatedly reworked under periglacial conditions and thus became gradually part of 'new' fluvial deposits. The reworking resulted in a relative enrichment of garnet. A similar process has also been reported from an aeolian environment (Mycielska-Dowgiałło, 1995 , 2001), where also minerals from the mica group can become enriched (Barczuk \& Mycielska-Dowgiałło, 2001).

The differences in the mineral composition of the deposits from Masłowiec and Duraczów should be attributed to the relief of the Eagowica valley. At Masłowiec, the narrow gorge was more strongly affected by slope processes, initiated by the climate change. Consequently, the valley bottom was covered with weathered material accumulated after denudation of glacial boulder clays. The deposits in Duraczów, in contrast, accumulated in a wide valley in which the stream also carried sediments from a tributary stream (the Wszachówka river) (Fig. 6).

\section{Results and discussion}

The heavy-mineral assemblages of the Quaternary sediments, deposited in different sedimentary environments in the Kielce-Łagów valley, have some characteristic features but is not very diverse (Table 7, Fig. 14).

\subsection{Resistant minerals}

Transparent resistant minerals prevail in the weathering debris of Palaeozoic rocks (Devonian sandstones) (at the Huta Koszary and Koszary sites), as well as in the infillings of karst pits (at the Winna and Komorniki sites) and in periglacial sandy (Komorniki) and soliflucted flowtill (Koszary, Huta Koszary) slope deposits. With respect to the age, these deposits are the oldest, formed before the Odra glaciations; they include also Vistulian deposits (at Koszary and Huta Koszary) but these were derived from 'old' sedimentary covers. The ranking of the dominant heavy minerals can be described as $\mathrm{Z}>\mathrm{M}>\mathrm{T}, \mathrm{T}>\mathrm{Z}, \mathrm{K}>\mathrm{ST}>\mathrm{Z}$, $\mathrm{ST}>\mathrm{AM}>\mathrm{Z}$. These sediments form, in turn, one of the sources for later generations of deposits, which inherited their heavy minerals from this material. These younger deposits contain a high proportion of resistant heavy minerals, which results in a low analog weathering index (aW), ranging from 0 to 3.0 (Fig. 13). The values of the weathering index $(\mathrm{W})$ values range from 3 to 27 (Fig. 14).

Resistant minerals, such as zircon, staurolite, tourmaline and kyanite, belong to the dominant minerals or complementary minerals in all types of deposit, regardless of age and origin (Table 7). They differ only with respect to their percentage in the heavy-mineral assemblage. Together with other resistant minerals, they provide the mineralogical 


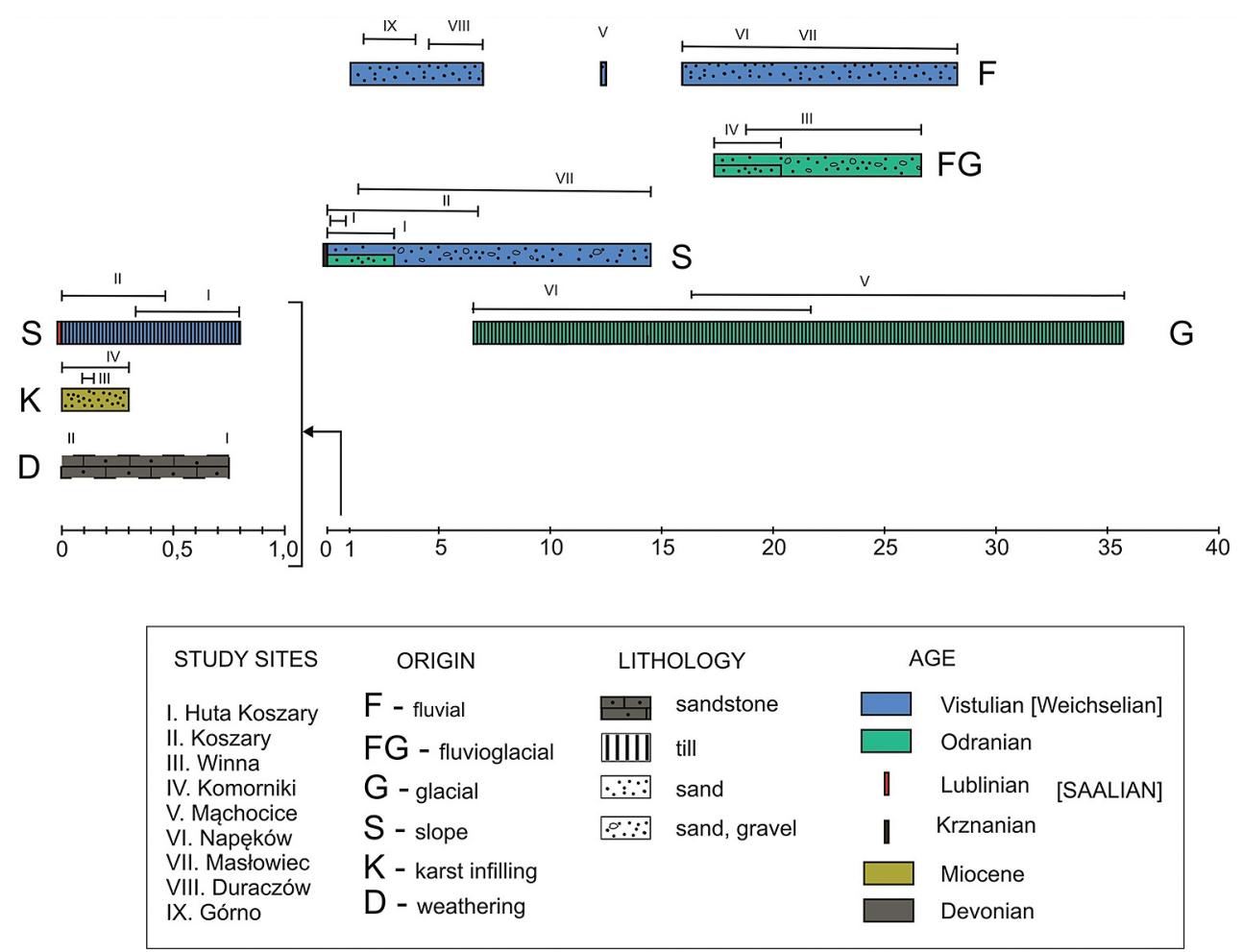

Fig. 14. The analog weathering index $(\mathrm{aW})$ of the Kielce-Łagów Valley Quaternary deposits of different lithology, depositional environment and age.

background for all other sediments under study here. The non-resistant minerals became weathered and gradually disappeared with time, which led to the relative enrichment of resistant minerals. Where the mineral assembly of relatively young deposits (i.e. the early Vistulian deposits at Górno) contains a truly large proportion of resistant minerals, it may be assumed, that 'old' deposits were reworked, for instance through erosion, denudation, or aeolian deflation. Thus it is possible to reconstruct the location that underwent erosion, the location of the source material, and the transport direction.

\subsection{Semi-resistant minerals}

Semi-resistant transparent minerals occur in large amounts in all sediments under study here. The early Vistulian fluvial deposits (Górno), the infillings of karst pits (Winna, Komorniki) and the weathered debris of Devonian rocks (Huta Koszary, Koszary) con- tain the lowest percentages of these minerals. They are represented mostly by garnet, and to a lesser extent by epidote. Garnet is one of the most dominant minerals in the periglacial slope deposits, the fluvial, the glacial and the fluvioglacial deposits (Table 7 ). The relative enrichment of garnet results from their repeated reworking and their gradual embedding in freshly formed fluvial sediments, which is particularly clear for relatively young deposits (e.g. at Masłowiec). This phenomenon is well known also from other fluvial and fluvioglacial areas (Mycielska-Dowgiałło, 1978; Florek et al., 1987; Mycielska-Dowgiałło \& Rutkowski, 1995; Ludwikowska-Kędzia, 2000). A similar relative enrichment of garnet is also known from the aeolian environment (Mycielska-Dowgiałło, 1993, 1995, 2001). It is worth noting that Vistulian loesses in the area of the Middle-Polish uplands have an increased content of amphibole and epidote (Racinowski, 2008) and may be one of the sources of these minerals in the Quaternary deposits of the study area. 


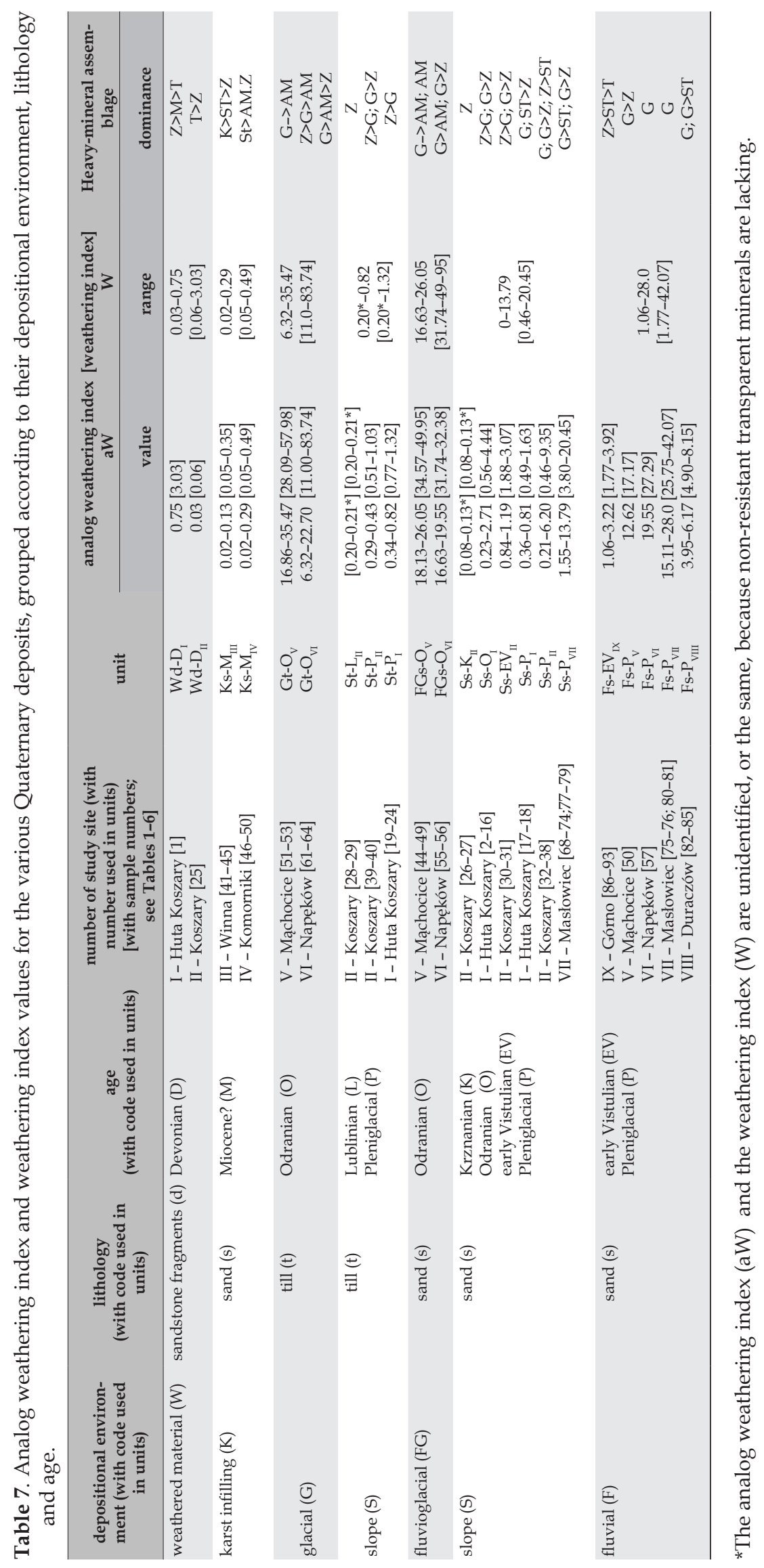




\subsection{Non-resistant minerals}

The most significant minerals in the non-resistant group are amphibole and pyroxene. Their proportion is commonly low. Amphiboles are present in the ranking $\mathrm{G}>\mathrm{Am}>\mathrm{Z}$ (epi,sta,tou), which is characteristic exclusively of glacigenic deposits (sites Mąchocice and Napęków) and of those formed as a result of the denudation of these deposits the Masłowice site.

\subsection{Source deposits and the role of reworking}

Another issue worth dealing with is the degree of exposure of the possible source deposits, and the likelihood of their reworking, which is controlled by the relief of the KielceŁagów Valley. Reworked deposits occur in the sub-slope parts of the Palaeozoic hilly areas, away from the axis of the Kielce-Łagów Val- ley. These are most frequently mature slopes, with a small gradient, so that the transportation of material to the valley bottom is not so easy. Only slight modifications of the mineral composition occur in increasingly younger deposits, because of the short time that was present for modification of the heavy-mineral assemblage, the low intensity of the modification processes, and the dominance of resistant minerals (which obscures slight modifications in the total assemblage. Consequently, garnet, amphibole and pyroxene, i.e. minerals of which the main source are glacigenic deposits, can be considered as diagnostic minerals. The relative enrichment in garnet results from their repeated reworking and from their gradual embedding in freshly formed fluvial sediments. The presence of amphibole and pyroxene must be ascribed to denudation of glacigenic deposits, which are common in the wide and flat bottom of the Kielce-Łagów Valley.

The influence of the second source of the heavy minerals, i.e. the glacigenic deposits that

\begin{tabular}{|c|c|c|c|c|c|c|c|c|c|c|c|c|c|c|}
\hline \multirow{2}{*}{$\begin{array}{l}\text { sample } \\
\text { number }\end{array}$} & \multirow{2}{*}{$\begin{array}{c}\text { transparent } \\
\text { minerals } \\
T\end{array}$} & \multirow{2}{*}{$\begin{array}{c}\text { opaque } \\
\text { minerals } \\
0\end{array}$} & \multicolumn{5}{|c|}{ TRANSPARENT+OPAQUE MINERALS $=100 \%$} & \multicolumn{5}{|c|}{ TRANSPARENT MINERALS $=100 \%$} & \multirow{2}{*}{$\frac{\mathrm{W}}{\mathrm{aW}}$} & \multirow{2}{*}{$\frac{T}{O}$} \\
\hline & & & $\begin{array}{l}\text { semi- } \\
\text { resistant } \\
\text { SR }\end{array}$ & $\begin{array}{c}\text { resistant } \\
\mathrm{R} \\
\end{array}$ & $\begin{array}{l}\text { non- } \\
\text { resistant } \\
\text { NR }\end{array}$ & $\frac{S R}{R}$ & $\begin{array}{c}\text { analog } \\
\text { weathering } \\
\text { index (aW) }\end{array}$ & $\begin{array}{c}\text { semi- } \\
\text { resistant } \\
\text { SR }\end{array}$ & $\begin{array}{c}\text { resistant } \\
\text { R }\end{array}$ & $\begin{array}{c}\text { non- } \\
\text { resistant } \\
\text { NR }\end{array}$ & $\frac{S R}{R}$ & $\begin{array}{l}\text { weathering } \\
\text { index } \\
\text { (W) }\end{array}$ & & \\
\hline 45 & 15.3 & 84.7 & 0.1 & 10.9 & 4.3 & 0.01 & 0.04 & 0.9 & 71.3 & 27.9 & 0.01 & 0.35 & 8.75 & 0.18 \\
\hline 47 & 29.9 & 70.1 & 0.3 & 27.8 & 1.8 & 0.01 & 0.02 & 1.1 & 93.0 & 5.9 & 0.01 & 0.07 & 3.50 & 0.43 \\
\hline 61 & 35.6 & 64.4 & 13.6 & 10.8 & 11.2 & 1.26 & 14.10 & 37.9 & 30.0 & 31.5 & 1.26 & 39.00 & 2.76 & 0.55 \\
\hline 19 & 49.0 & 51.0 & 21.4 & 26.9 & 0.6 & 0.79 & 0.48 & 43.8 & 54.9 & 1.3 & 0.79 & 1.04 & 2.17 & 0.96 \\
\hline 55 & 49.9 & 50.1 & 22.3 & 14.2 & 13.4 & 1.57 & 21.04 & 44.6 & 28.5 & 26.9 & 1.57 & 42.10 & 2.00 & 0.99 \\
\hline 50 & 57.8 & 42.4 & 1.4 & 48.3 & 8.1 & 0.03 & 0.23 & 2.5 & 83.4 & 14.1 & 0.03 & 0.42 & 1.83 & 1.36 \\
\hline 34 & 66.0 & 34.0 & 34.9 & 26.5 & 4.6 & 1.32 & 6.06 & 52.8 & 40.1 & 7.1 & 1.32 & 9.35 & 1.54 & 1.99 \\
\hline 56 & 67.2 & 32.8 & 9.7 & 15.6 & 41.9 & 0.62 & 26.05 & 14.4 & 23.3 & 62.3 & 0.62 & 38.50 & 1.47 & 2.05 \\
\hline 83 & 76.0 & 24.0 & 41.5 & 30.1 & 4.4 & 1.38 & 6.07 & 54.6 & 39.5 & 5.9 & 1.38 & 8.15 & 1.34 & 3.17 \\
\hline 85 & 82.8 & 17.2 & 39.0 & 38.9 & 4.9 & 1.00 & 4.91 & 47.2 & 47.0 & 5.8 & 1.00 & 5.82 & 1.19 & 4.81 \\
\hline
\end{tabular}

A

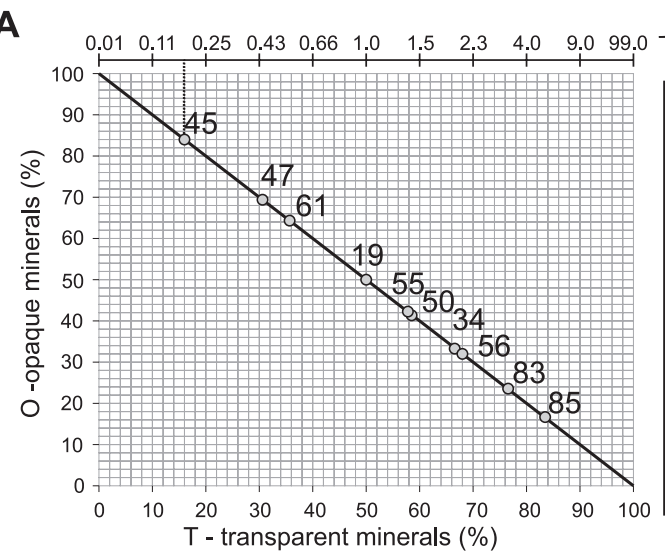

B

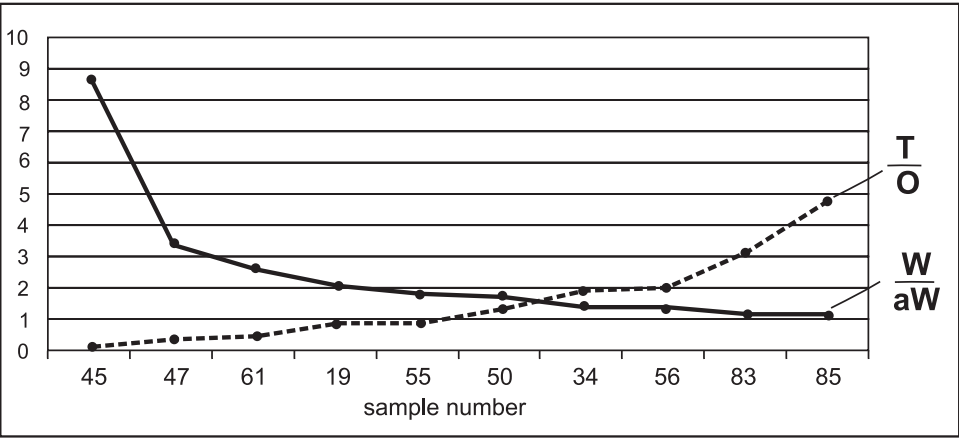

Fig. 15. Aspects of the proportionality index $(\mathrm{P})$.

A: Relationship between the proportion of transparent minerals $(\mathrm{T})$ in the various Quaternary deposits to that of the opaque minerals $(\mathrm{O})$. The lower the value of $\mathrm{P}$, the higher the proportion of opaque minerals in the sediment (and vice versa).

B: Changes in the proportionality index of the various Quaternary deposits and the W:aW ratio calculated for these deposits. 
were denudated, is evident in the increasingly younger sediments, even against the background of the inherited assemblage of resistant minerals.

\subsection{The analog weathering index $(\mathrm{aW})$ and weathering index $(\mathrm{W})$}

The dual character of the source material of the Quaternary deposits in the Kielce-Łagów Valley is typical of the zone of uplands and old mountains in Poland. This property is reflected in the value of the analog weathering index, $\mathrm{aW}$ and of the weathering index, $\mathrm{W}$. The $\mathrm{aW}$ and $\mathrm{W}$ values for the source deposits (Wd-D, Ks-M, Ss-O), which are dominated by resistant heavy minerals, are exceptionally low and range from 0.02 to 2.71 for aW, and from 0.05 to 4.44 for $W$. In the glacial and fluvioglacial deposits $(\mathrm{Gt}$, FGs), on the other hand, the aW ranges from 6.32 to 35.47 , and $W$ ranges from 11.08 to 83.74. Its value in younger, Vistulian deposits depends on the properties of the source deposits: it is lower in the case of a higher proportion of deposits with an assemblage dominated by resistant minerals (e.g. in the St-P Vistulian soliflucted till at the Huta Koszary, and Koszary sites, and in the Fs-P Vistulian fluvial sands at the Górno site), and higher in the case of a denudated glacial cover (e.g. at the the Masłowiec site). This relationship is also illustrated in the assemblages of the Holocene fluvial sediments in the Daleszyce profile (Ludwikowska-Kędzia, 2000), and of the Pleniglacial fluvial sediments in the Słopiec profile (Wachecka-Kotkowska \& Ludwikowska-Kędzia, 2007) in the valley of the Belnianka river, in the central part of the Holy Cross Mountains.

When the values obtained for the weathering index and the analog weathering index are mutually compared (Fig. 15), two important conclusions can be drawn:

(1) the proportion of particular transparent mineral groups (with respect to their resistance) is lower if calculated with the use of the aW index than if calculated with $\mathrm{W}$, and both values become increasingly lower with an increasing content of opaque minerals (i.e. the values of the proportionality index $[\mathrm{P}=\mathrm{T} / \mathrm{O}]$ become lower).

(b) if the value of the proportionality index diminishes (i.e. if the proportion of opaque minerals increases), the value of $\mathrm{W} /(\mathrm{aW})$ increases (i.e. the difference between the weathering index, $W$, and the analog weathering index, aW, increases). The values of both indexes will differ least from each other when the proportion of the transparent minerals reaches almost $100 \%(\mathrm{~T}+\mathrm{O}=\mathrm{T})$.

These findings indicate that it is important for analysis of the environmental conditions under which the sediment was formed and transformed to know the proportions of the transparent and opaque minerals (e.g. Marcinkowski, 2007), as well as their relation to each other as defined by the proportionality index $\mathrm{P}=\mathrm{T} / \mathrm{O}$, the weathering indexes $\mathrm{W}$ and $\mathrm{aW}$, and the relationship between these two indexes.

\section{Conclusions}

The heavy-mineral analysis of the Quaternary deposits in the Kielce-Łagów Valley leads to the following five conclusions.

1) The mineral assemblages of the Quaternary deposits in the Kielce-Łagów Valley, which have different ages and which accumulated in different environments, are not truly diverse. The assemblages depend on the origin and location of the source material. The resistant minerals, among which zircon, staurolite and tourmaline, are largely inherited from the oldest source material: weathering products of Devonian and Palaeogene-Neogene rocks, as well as Pleistocene glacigenic and, in the case of loess, aeolian material dating from before the Odranian glaciation. The semi-resistant and non-resistant minerals, mainly garnet, amphibole and epidote, are derived from the denudation of the youngest glacigenic deposits in the study area, i.e. tills and fluvioglacial sands from the Odranian glaciation.

2) There is a clear relationship between the heavy-mineral assemblages of the Quaternary deposits and the relief of the Kielce- 
Łagów Valley. The precise location of the deposits with regard to the relief controls, in combination with the nature of the local source material, the heavy-mineral assemblage. The oldest source deposits in which resistant minerals dominate, are found in the area of the sub-slope ranges of Palaeozoic hills. Their exposure to erosion decreased with time, because of the diminishing slope gradient and because they became gradually overlain by a younger sedimentary cover. The bottom of the Kielce-Łagów Valley, on the other hand, is covered with glacigenic deposits which, due to the low relief in the valley, were only slightly subjected to denudation and erosion, but more to aeolian activity. Consequently, the fluvial environment of the Kielce-Łagów Valley resulted in hardly varying mineral assemblages.

3) The heavy-mineral compositions of tills with a known stratigraphic position (and thus also a known age) in the glacial and periglacial slope environments are diagnostic, so that they can be used to distinguish between both types of tills. This is of great importance for the understanding of the regional Quaternary geology in this part of the Holy Cross Mountains. In this context, the weathering index also deserves attention. For glacial clays, the aW index ranges from 6.32 to 35.47 , whereas it does not exceed 1 for periglacial soliflucted flowtills. The differences are also evident in the $W$ values: for glacial tills, $W$ amounts to 11-83.74 and for periglacial, soliflucted flowtills $\mathrm{W}$ is $0.51-1.32$. $\mathrm{W}$ is especially low in comparison to the glacial deposits of northern Poland (where it ranges from 50 to over 200) (a.o. Racinowski \& Rzechowski; 1969, Cichosz-Kostecka et al., 1991).

4) The heavy-mineral analysis is an additional tool in determining the age and origin of Quaternary deposits. In order to take full advantage of this possibility, it is important to obtain a good insight into the mineralogical background of the area at both a local and a regional scale (Racinowski \& Rzechowski, 1969; Racinowski, 2008) before heavy-mineral analyses are carried out. Only then is it possible to interpret the results of such an analysis in a reliable way.

5) The heavy-mineral analyses of the Quaternary sediments indicate an advanced weathering process. This implies that the Pleistocene land-ice mass did not affect the local and regional mineralogical background of sediments considerably. The flowing ice mass eroded mainly local material, consisting largely of resistant minerals from the weathered bedrock. Under the changeable climatic conditions of the Pleistocene, the deposits underwent aeolian processes and chemical weathering, which modified their original mineral composition.

\section{Acknowledgements}

This work was supported by a grant from the Ministry of Science and Higher Education (MNiSW), No. N306 129337. The author thanks M.Sc. J. Bugajska (Geological Enterprise in Kielce), Dr Eng. B. Marcinkowski (PIG-BIP Warsaw) and Prof. Karwowski (University of Silesia) for carrying out heavy-mineral analyses. I would like to thank Prof. E. Mycielska-Dowgiałło, Dr M. Wiatrak and Dr M. Kosztołowicz for fruitful discussions.

\section{References}

Anketell, J.M., Cegła, J. \& Dżułyński, S., 1970. On the deformational structures in systems with reversed density gradients. Rocznik Polskiego Towarzystwa Geologicznego 40, 3-30.

Barcicki, M., Cichosz- Kostecka, A., Goździk, J., Mycielska-Dowgiałło, E. \& Prószyńska-Bordas, H., 1988. Sedimentologic analysis of thick deposits in the karst pit at the $\mathrm{N}$ border of Holy Cross Mountains (Poland). Miscellanea Geographica, 55-67.

Barczuk, A. \& Mycielska-Dowgiałło, E., 2001. Znaczenie składu mineralnego osadów dla rozpoznawania obecności procesów eolicznych [The importance of the mineral composition of sediments for recognition of the presence of aeolian processes]. [In:] E. Mycielska-Dowgiałło (Ed.): Eolizacja osadów jako wskaźnik stratygraficzny czwartorzedu. [Aeolisation of sediments as an indicator of Quaternary stratigraphy]. WGiSR UW, Warszawa, 39-42.

Barczuk, A. \& Nejber, K., 2008. Analiza minerałów nieprzeroczystych $\mathrm{w}$ badaniach skał okruchowych [The analysis of opaque minerals in the study of clastic rocks]. [In:] E. Mycielska-Dowgiałło \& J. Rutkowski (Eds): Badania cech teksturalnych osadów czwartorzędowych i wybrane metody oznaczania ich wieku [Investiga- 
tion of the textural features of Quaternary sediments and some dating methods]. The Family Alliance School of Higher Education Press, Warsawa, 205-228.

Bateman, R.M. \& Catt, J.A., 2007. Provenance and palaeoenvironmental interpretation of superficial deposits, with particular reference to post-depositional modification of heavy mineral assemblages. [In:] M.A. Mange \& D.T. Wright (Eds): Heavy minerals in use. Developments in Sedimentology 58, 151-188.

Cichosz-Kostecka, A., Mycielska-Dowgiałło, E. \& Manikowska, B., 1991. Late Glacial aeolian processes in the light of sediment analysis from Kamion profile near Wyszogród. Zeitschrift für Geomorphologie Neue Folge, Supplement Band 90, 45-50.

Czarnocki, J., 1957. Tektonika Gór Świętokrzyskich. Stratygrafia i tektonika Gór Świętokrzyskich [Tectonics of the Holy Cross Mountains. Stratigraphy and tectonics of the Holy Cross Mountains]. Prace Instytutu Geologicznego 2, 1-133

Fijałkowska, E. \& Fijałkowski, J., 1971. Zaplecze surowcowe ośrodka garncarskiego $\mathrm{w}$ Łagowie [A resource centre of pottery in Lagow]. Rocznik Muzeum Świętokrzyskiego 7, 185-224.

Florek, W., Florek, E. \& Mycielska-Dowgiałło, E., 1987. Morphogenesis of the Vistula valley between Kępa Polska and Płock in the Late Glacial and Holocene. [In:] L. Starkel (Ed.): Evolution of the Vistula River valley during the last 15000 years. Part II. Geographical Studies, Special Issue 4, 189-206.

Gilewska, S., 1991. Rzeźba [The relief]. [In:] L. Starkel (Ed.): Geografia Polski. Środowisko przyrodnicze [Geography of Poland. Natural environment]. Wydawnictwo Naukowe PWN, Warszawa, 248-296.

Harapińska-Depciuch, M., 1957. Petrografia piaskowców kwarcytowych dewońskich z Gór Świętokrzyskich [Petrography of the Devonian quartzitic sandstones of the Holy Cross Mountains]. Kwartalnik Geologiczny 1,169-173.

Klatka, T., 1962. Geneza i wiek gołoborzy łysogórskich [The origin and age of weathered covers in the Łysogóry Range]. Acta Geographica Lodziensia 12, $1-124$.

Komar, P.D., Clemens, KE., Li, Z. \& Shih, S.M., 1989. The effects of selective sorting on factor analysis of heavy mineral assemblages. Journal of Sedimentary Petrology 59, 590-596.

Kowalski, B., Gromada, E. \& Swałdek, M., 1979. Granulometryczna i litologiczno-petrograficzna charakterystyka gliny zwałowej z Doliny Wilkowskiej w Górach Świętokrzyskich [Granulometrical and litho-petrographical characteristics of boulder clay from the Wilkowska valley in the Holy Cross Mountains]. Rocznik Polskiego Towarzystwa Geologicznego 49, 343-377.

Krysowska-Iwaszkiewicz, M., 1974. Studium mineralogiczno-petrograficzne kenozoicznych osadów lądowych Wyżyny Krakowskiej [Mineralogical and petrographical study of the Cenozoic continental deposits of the Cracovian upland]. Prace Mineralogiczne 35, $1-75$.
Kubala-Kukuś, A., Ludwikowska-Kędzia, M., Banaś, D., Braziewicz, J., Majewska, U., Pajek, M. \& WudarczykMoćko, J., 2013. Application of the X-ray fluorescence analysis and X-ray diffraction in geochemical studies of the Pleistocene tills from Holy Cross Mountains. Radiation Physics and Chemistry (in press).

Linder, L., 1984. Region świętokrzyski [The Holy Cross Region]. [In:] J.E. Mojski (Ed.): Budowa geologiczna Polski. T. 1. Stratygrafia. Cz. 3b. Kenozoik - czwartorzęd [Geology of Poland. Vol. 1. Stratigraphy. Part 3b. Cenozoic Quaternary], 33-35, 65-73, 113-145, 255-286, 326-330.

Lindner, L., 2004. Zarys stratygrafii plejstocenu regionu świętokrzyskiego w świetle nowych danych [Outline of the Pleistocene stratigraphy of the Holy Cross Mountains area in the light of new data]. Prace Instytutu Geografii Akademii Świętokrzyskiej w Kielcach 13, 7-31.

Lindner, L. \& Bogucki, A., 2002. Pozycja wiekowa środkowo- i późnoplejstoceńskich zjawisk peryglacjalnych w środkowo-wschodniej Europie [The age of Middle and Late Pleistocene periglacial phenomena in central and eastern Europe]. Prace Instytutu Geografii Akademii Świętokrzyskiej w Kielach 8, 81-106.

Lindner, L. \& Marks, L., 2012. O podziale klimatostratygraficznym kompleksu środkowopolskiego w plejstocenie Polski [Climatostratigraphic subdivision of the Pleistocene Middle Polish Complex in Poland]. Przegląd Geologiczny 60, 36-45.

Ludwikowska-Kędzia, M., 2000. Ewolucja środkowego odcinka doliny rzeki Belnianki w późnym glacjale i holocenie [Evolution of the middle segment of the Belnianka River valley in the Late Glacial and Holocene]. Wydawnictwo Akademickie Dialog, Warsaw, 180 pp.

Ludwikowska-Kędzia, M., 2007. Wybrane cechy strukturalne i teksturalne deluwiów Pasma Bielińskiego w rejonie Huty Starej Koszary i ich wymowa paleogeograficzna [Selected structural and textural features of slope deposits of the Belińskie range in the Huta Stara Koszary area and its palaeogeography]. Prace Instytutu Geografii Akademii Świętokrzyskiej w Kielcach 8, 95-113.

Ludwikowska-Kędzia, M. \& Olszak, I., 2009. Litologia i stratygrafia peryglacjalnych osadów stokowych Pasma Bielińskiego w rejonie Huty Starej Koszary [Lithology and stratigraphy of periglacial slope sediments of the Bielińskie range near Huta Stara Koszary]. [In:] M. Ludwikowska-Kędzia \& M. Wiatrak (Eds): Znane fakty - nowe interpretacje w geologii i geomorfologii Gór Świętokrzyskich [Familiar facts - new interpretations of the geology and geomorphology of the Holy Cross Mountains]. Institute of Geography, Jan Kochanowski University, Kielce, 75-89.

Ludwikowska-Kędzia, M. \& Pawelec, H., 2011. Osady glacigeniczne w rejonie Mąchcocic Kapitulnych [Glacigenic sediments near Mąchocice Kapitulne]. [In:] M. Ludwikowska-Kędzia \& M. Wiatrak (Eds): Geologia i geomorfologia Regionu Świętokrzyskiego [Geology and geomorphology from the Holy Cross region]. Institute of Geography, Jan Kochanowski University, Kielce, 71-87. 
Ludwikowska-Kędzia, M., Wiatrak, M., Olszak, I. \& Bluszcz, A., 2006. Litostratygrafia tarasu nadzalewowego doliny rzeki Łagowicy w rejonie Masłowca (SE Gór Świętokrzyskich) [Lithostratigraphy of the Pleistocene high meadow terrace of the Łagowica valley near Masłowiec (SE Holy Cross Mountains)]. Przegląd Geologiczny 11, 953-962.

Łyczewska, J., 1971. Czwartorzęd regionu świętokrzyskiego. Stratygrafia kenozoiku Gór Świętokrzyskich i ich obrzeżenia [Quaternary of the Holy Cross Mountains region. Cenozoic stratigraphy of the Holy Cross Mountains and its margin]. Prace Instytutu Geologicznego 42, 5-86.

Marcinkowski, B., 2007. Wykorzystanie składu mineralnego i morfologii ziaren minerałów ciężkich do określania środowiska sedymentacyjnego [Application of mineral composite and morphologic grain minerale in designation of sedimentary environment]. Przeglad Geologiczny 55, 207.

Marks, L., 2011. Quaternary glaciations in Poland. Developments in Quaternary Science 15, 299-303.

Miall, A.D., 1978. Lithofacies types and vertical profile models in braided river deposits: a summary. Fluvial sedimentology. Canadian Society of Petroleum Geologists, Memoir 5, 597-604.

Miall, A.D. 1985. Architectural-element analysis: new method of facies analysis applied to fluvial deposits. Earth-Science Reviews 22, 261-308.

Michniak, R., 1969. Petrografia górnego prekambru (ryfeju) i kambru wschodniej części Gór Świętokrzyskich [Petrography of the late Precambrian (Riphaean) and Cambrian of the eastern part of the Holy Cross Mountains]. Studia Geologica Polonica 30, 1-98.

Mojski, J.E., 2005. Ziemie polskie w czwartorzędzie. Zarys morfogenezy [Poland in the Quaternary. Morphogenesis]. PIG, Warsaw, 405 pp.

Mycielska-Dowgiałło, E., 1965. Rozwój geomorfologiczny w południowo-wschodniej części Wyżyny Sandomierskiej $\mathrm{w}$ górnym miocenie i pliocenie [The geomorphological evolution of the south-eastern part of the Sandomierz upland in the upper Miocene and Pliocene]. Przeglad Geologiczny 37, 637-649.

Mycielska-Dowgiałło, E., 1978. Rozwój rzeźby fluwialnej pótnocnej części Kotliny Sandomierskiej w świetle badań sedymentologicznych [Evolution of the fluvial relief in the northern part of Sandomierz Basin in the light of sedimentological studies]. Rozprawy Uniwersytetu Warszawskiego 120, 1-167.

Mycielska-Dowgiałło, E., 1993. Estimates of Late Glacial and Holocene aeolian activity in Belgium, Poland and Sweden. Boreas 22, 165-170.

Mycielska-Dowgiałło, E., 1995. Wybrane cechy teksturalne osadów i ich wartość interpretacyjna [Some textural features and interpretation opportunities]. [In:] E. Mycielska-Dowgiałło \& J. Rutkowski (Eds): Badania osadów czwartorzędowych. Wybrane metody i interpretacja wyników [The investigation of Quaternary deposits. Selected methods and interpretation of the results]. Warsaw University, Warszawa, 29-105.

Mycielska-Dowgiałło, E. (Ed.), 2001. Eolizacja osadów jako wskaźnik stratygraficzny czwartorzędu [Aeolisation of sed- iments as an indicator of Quaternary stratigraphy]. Warsaw University Warszawa, $141 \mathrm{pp}$.

Mycielska-Dowgiałło, E., 2007. Metody badań cech teksturalnych osadów klastycznych i wartość interpretacyjna wyników [Research methods for textural features of clastic deposits and the significance of interpretational results]. [In:] E. Mycielska-Dowgiałło \& J. Rutkowski (Eds): Badania cech teksturalnych osadów czwartorzędowych $i$ wybrane metody oznaczania ich wieku [Investigation of the textural features of Quaternary sediments and some dating methods]. The Family Alliance School of Higher Education Press, Warsaw, 95-180.

Racinowski, R., 1995. Analiza minerałów ciężkich w badaniach osadów czwartorzędowych Polski [Analysis of heavy minerals in studies of Quaternary sediments from Poland]. [In:] E. Mycielska-Dowgiałło \& J. Rutkowski (Eds), Badania osadów czwartorzędowych. [Investigation of Quaternary deposits]. WGiSR UW, Warszawa, 151-166.

Racinowski, R., 2008. Znaczenie analizy minerałów ciężkich w badaniach osadów czwartorzędowych Polski [Significance of heavy-mineral analysis for the study of Quaternary deposits in Poland]. Annales Universitatis Mariae Curie-Skłodowska, section B 63, 7-44.

Racinowski, R., 2010. Główne przeźroczyste minerały ciężkie w osadach czwartorzędowych Polski [Main transparent heavy minerals in Quaternary deposits of Poland]. Biuletyn Państwowego Instytutu Geologicznego, 438, 99-106.

Racinowsk, R. \& Rzechowski, J., 1969. Minerały ciężkie w glinach zwałowych Polski środkowej [Heavy minerals in glacial tills of central Poland]. Kwartalnik Geologiczny 13, 479-490.

Radłowska, C. \& Mycielska-Dowgiałło, E., 1972. Uwagi o deglacjacji zachodniej części Gór Świętokrzyskich (w okolicach Chęcin) [Comments on the deglaciation of the western part of the Holy Cross Mountains (near Chęciny)]. Przegląd Geograficzny 44, 650-672.

Radziszewski, P., 1928. Przyczynek do petrografii dolnego kambru we wschodniej części Gór Świętokrzyskich [Contribution to the petrography of the lower Cambrian in the eastern part of the Holy Cross Mountains]. Sprawozdania Państwowego Instytutu Geologicznego 4, 500-532.

Starkel, L., 2008. Paleogeograficzne korzenie współczesnej rzeźby Polski [Palaeogeographic roots of the contemporary relief of Poland]. [In:] L. Starkel, A. Kostrzewski, A. Kotarba \& K. Krzemień (Eds): Wspótczesne przemiany rzeźby Polski [Contemporary transformations of Poland's relief]. Instytut Geografii i Gospodarki Przestrzennej, Uniwersytetu Jagiellońskiego, Kraków, 13-20.

Tarnowska, M., 1971. Dolnodewonskie skały polimiktyczne i tufogeniczne w regionie kieleckim Gór Świętokrzyskich [Lower Devonian polymict and tufaceous rocks in the Kielce region of the Holy Cross Mountains]. Kwartalnik Geologiczny 15, 569-588.

Urban, J., 2001. Kras kopalny trzonu paleozoicznego Gór Swiętokrzyskich [Fossil karst in the Palaeozoic bedrock of the Holy Cross Mountains]. Unpublished Ph.D. thesis 
UAM Poznań, Archiwum PIB-PIB Oddział Świętokrzyski, 295 pp.

Urban, J. \& Rzońca, B., 2009. Karst systems analyzed using borehole logs - Devonian carbonates of the Świętokrzyskie (Holy Cross) Mountains, central Poland. Geomorphology 112, 27-47.

Van Loon, A.J., 2009. Soft-sediment deformation structures in siliciclastic sediments: an overview. Geologos 15, 3-55.

Wachecka-Kotkowska, L. \& Ludwikowska-Kędzia, M., 2007. Plenivistuliański poziom wysoki w dolinach rzek Luciąży (Równina Piotrkowska/Wzgórza Radomszczańskie) i Belnianki (Góry Świętokrzyskie). Porównanie cech strukturalnych i teksturalnych osadów [The Plenivistulian level in the Luciąża (Piotrków Plateau/Radomsko Hills) and Belnianka (Holy Cross Mountains) river valleys. Comparison of structural and textural features of the deposits]. Acta Geographica Lodziensia 93, 107-132.

Walczowski, A., 1962. Zjawiska krasowe w utworach paleozoicznych w okolicy Łagowa [The karst phenomenon in the Palaeozoic formations near Łagów]. Przegląd Geologiczny 9, 457-460.
Walczowski, A., 1964. Szczegótowa mapa geologiczna Polski w skali 1 : 50 000, ark. Łagów (853) [Detailed geological map of Poland at scale 1: 50 000, sheet Łagów]. Wydawnictwo Geologiczne, Warszawa.

Walczowski, A., 1968. Objaśnienia do Szczegótowej mapy geologicznej Polski w skali 1:50 000, ark. Łagów (853) [Explanations to the detailed geological map of Poland at scale 1:50 000, sheet Łagów]. Wydawnictwo Geologiczne, Warsaw, $82 \mathrm{pp}$.

Wróblewski, T., 1977. Rzeźba Gór Świętokrzyskich [Relief of the Holy Cross Mountains]. Rocznik Świętokrzyski Kieleckiego Towarzystwa Naukowego 5, 9-22.

Zieliński, T. \& Pisarska-Jamroży, M., 2012. Jakie cechy litologiczne warto kodować, a jakie nie? [Which features of deposits should be included in codes and which not?] Przeglad Geologiczny 60, 387-397.

Manuscript received: 1 February 2013 Revision accepted: 6 March 2013 